Hispania Sacra, LX

121, enero-junio 2008, 297-329, ISSN: 0018-215-X

\title{
SOTANAS, ESCAÑOS Y SUFRAGIOS. PRÁCTICA POLÍTICA Y SOPORTES SOCIALES DEL NEO-CATOLICISMO EN LAS PROVINCIAS CASTELLANO-MANCHEGAS (1854-1868)
}

\author{
POR \\ JuAN ANTONIO INAREJos MUÑOZ \\ Universidad de Castilla-La Mancha
}

\section{RESUMEN}

En las Cortes Constituyentes de 1854 se plantearon cuestiones hasta entonces inéditas en las relaciones Iglesia-Estado: tolerancia de cultos, libertad religiosa o confesionalidad del Estado. El clero, cuya injerencia en las confrontaciones políticas no era en absoluto novedosa, se posicionó de forma mayoritaria al lado de una de las fracciones del partido moderado que, contradictoriamente, utilizó los nuevos mecanismos de representación política surgidos con el Estado representativo de la ciudadanía (prensa y representación parlamentaria), para combatir el liberalismo. Desde el púlpito, la prensa, la tribuna parlamentaria y la imprenta se emprendió una defensa de los derechos de la Iglesia orientada a la sacralización de la sociedad. Constituyen los principales trazos de un análisis que toma como referente las provincias que en la actualidad constituyen Castilla-La Mancha, donde la corriente neo-católica gozó de un relativo apoyo electoral y contó con la cobertura ideológica, numérica y organizativa proporcionada por el Arzobispado de Toledo y la diócesis conquense.

PALABRAS CLAVE: Reinado Isabel II, Partidos políticos, Relaciones Iglesia-Estado, Formas de acción política, Sufragio censitario.

\section{ABSTRACT}

In the Spanish Constituent assembly of 1854 some previously unknown issues were raised about Church-State relations, including tolerance of worshipping and religious freedom. The clergy, whose interference in political confrontations was nothing new, placed themselves as a majority alongside one of the factions of the Moderate party, which, in a contradictory way, used the new 
mechanisms of political representation arisen with the representative State of the citizen (The press and Parliamentary representation) to fight against liberalism.

A defense of Church rights directed towards the sacralization of society was undertaken by the pulpit, the press, the parliamentary tribune and the Printing press. These represented the main lines of an analysis which wakes reference to the provinces that nowadays make up Castilla-La Mancha, where the neocatholic brend had a reasonable electoral support and relied on the ideological, numerical and organizational support provided by the Archbishopric of Toledo and the diocese of Cuenca.

KEY WORDS: Elizabeth the second Kingdom, Political Parties, Chuch-State relationships, Ways of political action and limited suffrage.

Recibido/Received 07-04-2007

Aceptado/Accepted 02-09-2007

¿Qué se entiende por neo-catolicismo? Nadie ha dado, que sepamos, una definición seria y razonable. Se abusa de la palabra, y no se la explica; esto puede ser una obra de la ignorancia, y puede ser también obra de la malicia (...) La escuela neo-católica es una especie de fénix científico y político, de quien todo el mundo habla y que nadie en el mundo ha visto. ¿Nadie?... ¿Nadie ha visto la escuela neo-católica? ¿Nadie ha leído las obras de Maistre, de Chateaubriand y de Donoso Cortés? ¿Nadie ha observado la marcha de ciertos políticos? ¿Nadie ha comprendido que sobre los preceptos y verdades de la religión hay quien desea fundar y organizar todo un sistema político? ¿Nadie ha parado mientes en la influencia que al clero dan algunos hombres, y en el empeño que muestran por enfervorizarse a toda hora y aparecer en puntos de autoridad más realistas que el rey, y en puntos de religión más papistas que el pontífice?1

En 1862 el moderado conquense Severo Catalina esbozaba, no sin ciertas vacilaciones, algunos de los principales trazos del grupo neo-católico en cuyas filas recaló un año más tarde. Lo hacía en el capítulo de un opúsculo consagrado a rebatir los ataques vertidos por los enemigos del catolicismo. El testigo de Catalina fue recogido por Begoña Urigüen hace ya dos décadas, autora que sistematizó sus rasgos más significativos. Fue un grupo de opinión y de acción política no institucionalizado cuyo origen hay que rastrearlo en las filas del ala más reaccionaria del Partido moderado ${ }^{2}$. No llegó a configurarse como un partido independiente. Sus elementos, imbuidos de las doctrinas sustentadas por Donoso Cortes a partir de 1848, se aglutinaron en torno a Cándido Nocedal y se identificaron con los planteamientos de la Iglesia a partir de 1854. A partir de este momento, desde el púlpito, la prensa, el parlamento y la imprenta, se impulsó una defensa de los derechos de la Iglesia y de una política católica que, a

\footnotetext{
${ }^{1}$ Severo Catalina, La verdad del progreso, Madrid, Librería A. de San Martín, 1862, Capítulo VIII, I Parte.

2 Begoña URIGÜEn, Orígenes y evolución de la derecha española: el neo-catolicismo, CSIC, Madrid, 1986, pp. 106-136.

Hispania Sacra, LX

121, enero-junio 2008, 297-329, ISSN: 0018-215-X
} 
finales del reinado isabelino, condujo a una ruptura y enfrentamiento directo con el liberalismo.

Se conocen bien sus fundamentos ideológicos y los perfiles biográficos de sus principales adalides ${ }^{3}$. Sin embargo son todavía campos apenas hoyados su base social, el deslinde de sus referentes movilizadores, el desmenuzamiento de sus formas de acción política más allá de los principales centros de poder o el escudriñamiento de la influencia ejercida por el clero en la política del periodo bajoisabelino. Esto es especialmente claro en unas provincias rurales y agrarias, arquetípicas de la España del momento, como las que en la actualidad constituyen Castilla-La Mancha.

\section{LOS PRIMEROS ESFUERZOS ORGANIZATIVOS}

La etapa de vidriosas relaciones entre Estado e Iglesia que caracterizó los primeros pasos de la andadura liberal entró en un periodo de impasse a partir de 1851 tras la firma del Concordato impulsado por Bravo Murillo. Culminaron así formalmente los esfuerzos del moderantismo por atraerse al estamento ecle-

\footnotetext{
${ }^{3}$ En relación a las teorías ilustradas que intentaron salvar la separación entre política y moral católica impulsada por algunas corrientes racionalistas a finales del siglo XVIII, consúltese José María Portillo VAldÉs, Revolución de Nación. Orígenes de la cultura constitucional en España, 1780-1812, Madrid, CEPC, 2000, pp. 33-58. Un acercamiento teórico a la concepción neo-católica de la representación política (desazón hacia el sistema representativo y el régimen liberal, rechazo del sufragio universal, defensa de una constitución histórica basada en la religión y la monarquía, modelo representativo de carácter corporativo y defensa del mandato imperativo) en Rafael ZuRITA, María Antonia PEÑa y María SIERRA, «Los artífices de la legislación electoral: una aproximación a la teoría del gobierno representativo en España (1845-1870)», Hispania LXVI/223 (2006), pp. 665-666; y José Ramón URQUIJO GoITIA: «La representación desde el antiliberalismo», Ayer, 61 (2006), pp. 163-187. Junto a la obra de Urigüen -la mejor monografía de conjunto realizada hasta el momento-, véase, para una profundización en relación a sus fundamentos doctrinales (tradicionalismo donosiano, el catolicismo liberal balmesiano y el carlismo), la síntesis de Antonio RIVERA GARCÍA, Reacción y revolución en la España liberal, Madrid, Biblioteca Nueva, 2006, pp. 23-28 y 157-280. Como oposición al pensamiento progresista y racionalista -y de forma especial al Krausismo- desde posiciones ultraclericales y marcadamente antiliberales; Gonzalo CAPELLÁN De Miguel y Fidel Gómez OCHOA, El marqués de Orovio y el conservadurismo liberal del siglo XIX, Logroño, Instituto de Estudios Riojanos, 2003, pp. 121-159. En relación a sus puntos de confluencia con el carlismo, sobremanera a partir del reconocimiento del Reino de Italia en 1865; Jordi CANaL: El carlismo. Dos siglos de contrarrevolución en España, Madrid, Alianza, 2003, pp. 148-160; y Julio ARóstegui, Jordi CANAL, y Eduardo GonZÁlez CALLEJA, Las guerras carlistas. Hombres, hechos e ideas, Madrid, La Esfera de los Libros, 2003, p. 188. Los perfiles biográficos de uno de sus principales ideólogos, en Rafael Olivar BERTRAND, Aparisi y Guijarro, Madrid, IEP, 1962; José Luis VILlaCORTA BAÑOS, La exigencia moral en la política. Antonio Aparisi y Guijarro, Valencia, Tirant lo Blanc, 1994, y María Cruz RoMEO MATEO, «Política católica para después de la revolución o las vías del antiliberalismo: Aparici y Guijarro, 1843-1844», Trienio, 41 (2003), pp. 133-162.
} 
siástico y reconciliarse con él desde su ascenso al poder en $18444^{4}$. Consumada la principal embestida privatizadora contra las propiedades de la Iglesia, la burguesía moderada fue consciente de la funcionalidad de aquella y de la religión dentro del nuevo orden socioeconómico. No se podía renunciar al catolicismo. Allende su función social integradora, que permitía legitimar la desigualdad en aras del orden social, sirvió de pragmático dique contra la difusión de doctrinas «subversivas» ${ }^{5}$. Una vez sellado el apaciguamiento, la instrumentalización de las creencias religiosas por parte de las clases propietarias fue palmaria. Baste recordar el oficio que el Ayuntamiento ciudadrealeño, órgano donde se encontraban representados los intereses de los principales terratenientes de la capital, dirigió al Vicario a mediados de 1858:

«Últimamente se acordó por el Ayuntamiento que en consideración que todos los labradores y braceros de esta capital se hallan ocupados en la recolección del fruto de cereales, se dirija atenta comunicación al Sr. Vicario Eclesiástico de la misma, rogándole se sirva dispensar su asentimiento para que aquellos puedan trabajar en los días feriados sin incurrir en pecado mortal» ${ }^{6}$.

En el plano educativo y doctrinal la Iglesia recuperó y reafirmó amplias competencias. Las atribuciones en materia de instrucción sancionadas por el Concordato consagraron la conformidad de toda la enseñanza con el dogma y la moral católicas. Así quedó ratificado por la Ley Moyano de 1857, no obstante la importante capacidad de maniobra que, como ha señalado Pérez Garzón, se reservó el Estado en esta materia ${ }^{7}$. En 1851 también quedó aquilatada la confesionalidad del Estado que desde 1845 había cerrado la puerta a pretéritas ambigüedades y veleidades laicistas en su tratamiento constitucional ${ }^{8}$. La constricti-

\footnotetext{
${ }^{4}$ El contexto político y los principales rasgos del Concordato, en José Manuel CuENCA ToRIBIO: Relaciones Iglesia-Estado en la España contemporánea (1833-1985), Madrid, Alhambra, 1985, pp. 19; William CALlaHAN: Iglesia, poder y sociedad en España, 1750-1874, Madrid, Nerea, 1989; y Juan Pérez Alhama: La Iglesia y el Estado español: estudio histórico-jurídico a través del Concordato de 1851, Madrid, Instituto de Estudios Políticos, 1967.

${ }^{5}$ Un análisis de los efectos desmovilizadores de la religión y de su ambivalente papel como componente fundamental en la toma de conciencia de las «clases subordinadas», en Max WEBER, Sociología de la Religión, Madrid, Istmo, 1997; y Alicia Mira ABAD, Secularización y mentalidades. El Sexenio Democrático en Alicante (1868-1874), Alicante, Publicaciones de la Universidad de Alicante, 2006, pp. 17-25.

${ }^{6}$ Archivo Municipal de Ciudad Real (en adelante AMCR), Libros de Actas del Ayuntamiento de Ciudad Real, 2-VI-1858.

7 Juan Sisinio PÉrez GARZÓN, «El Estado educador: la secularización de la instrucción pública en España», Manuel SuÁREz CoRTina (ed.), Secularización y Laicismo en la España Contemporánea, Santander, Sociedad Menéndez Pelayo, 2001, p. 118.

8 Véase Remedios SÁNCHEZ FÉRRIZ,»Libertad religiosa y ciudadanía en las constituciones españolas del siglo XIX», Manuel SuÁreZ CorTina (ed.), Secularización y Laicismo..., op. cit., pp. 121-144; y Manuel Revuelta GonZÁleZ, «La Confesionalidad del Estado en España», Emilio La Parra y Jesús
}

Hispania Sacra, LX

121, enero-junio 2008, 297-329, ISSN: 0018-215-X 
va legislación de imprenta, complementó el artículo tercero del Concordato, fue un verdadero antídoto de censura frente a la publicación de libros malos o nocivos atentatorios contra la religión, el dogma, el culto y la moral pública9 9

El reconocimiento de Isabel II por parte del Vaticano significó una nueva vuelta de tuerca en el aislamiento del carlismo, de nuevo desarbolado tras el fracaso de las intentonas subversivas de finales de los cuarenta. A cambio el Estado insufló apoyo económico a la Iglesia a través de la dotación del culto y clero, mitigando los daños irrogados por la desamortización, cuyos demonizados rematantes se pudieron desprender del sambenito moral impuesto tras la adquisición de las jugosas propiedades privatizadas. La reactivación del proceso desamortizador entre 1854-1856 actuó, si bien en direcciones opuestas, como aglutinador de los embrionarios núcleos unionista y neo-católico.

La permanencia en el poder del Partido moderado había favorecido la unión de las diferentes tendencias hospedadas en su seno en torno al monolítico respaldo de la Corona y el disfrute de los recursos públicos. Su desahucio en 1854 desencadenó un proceso de relativa reorganización interna que se extendió hasta $1868^{10}$. El nuevo juego de poderes abierto con la entrada de los progresistas en la escena política situó a los moderados ante una nueva disyuntiva: permanecer alejados del poder o pasar a formar parte de la coalición ministerial capitalizada por Espartero y O'Donnell. Los moderados calificaron peyorativamente de apóstatas a los antiguos correligionarios que pasaron a engrosar las filas de

PRADElls (eds.), Iglesia, sociedad y Estado en España, Francia e Italia (ss. XVIII al XX), Alicante, Instituto Juan Gil-Albert, pp. 373-397.

${ }^{9} \mathrm{El}$ siguiente fragmento, publicado en la prensa ultramoderada, resulta aleccionador del tamiz ideológico impuesto por la jerarquía eclesiástica a lo largo del periodo isabelino: EEl señor cardenal arzobispo de Toledo acaba de prohibir dos novelas tituladas Los Miserables y La Judía Errante. El edicto en que se han publicado las prohibiciones de 9 de mayo, y en él se dice que habiendo sido denunciadas a su eminencia ambas producciones como abiertamente contrarias a la fe y las buenas costumbres, se sirvió pedir al Sr. vicario un ejemplar de lo impreso; y recibido, lo pasó a la censura de doctos eclesiásticos para que lo examinasen con toda detención y severa imparcialidad. Habiéndolo ejecutado los censores, han declarado unánimemente que la novela Los Miserables, su autor M. Víctor Hugo, contiene máximas y doctrinas inmorales, ideas anticristianas y antisociales, hechos y escenas dirigidas a desacreditar al episcopado, al clero católico, al principio de autoridad, y a toda clase de tribunales, halagando y sobreexcitando las malas pasiones. En cuanto a la novela La Judía Errante, prohibida ya por la autoridad eclesiástica de Barcelona, han declarado que contiene también máximas inmorales, pinturas y escenas deshonestas, injurias y calumnias contra una orden religiosa respetabilísima y otras congregaciones piadosas, con manifiesto empeño de hacer odiosas tan venerables instituciones. Y por último, que la lectura de entrambos libros es y debe considerarse sumamente perjudicial a las buenas costumbres, a la religión católica y al buen orden de la sociedad.», en La España, 28-V-1863. Una síntesis de las principales normativas de imprenta de la etapa, en José Ignacio MARCUELLO BENEDICTO, «La libertad de imprenta y su marco legal en la España liberal», Ayer, 34 (1999), pp. 65-91.

${ }^{10}$ Un estudio de las diferentes posiciones que cohabitaron dentro del partido en Francisco CÁnovas SÁnchez, El Partido Moderado, Madrid, Centro de Estudios Constitucionales, 1982, pp. 179-246; y José Luis Comellas, Los moderados en el poder, 1844-1854, Madrid, CSIC, 1970, pp. 142-150. 
la componenda gubernamental. Constituyó uno de los principales argumentos esgrimidos por los autoproclamados candidatos independientes a la hora de reclamar apoyo electoral. Fue el caso del arriacense Antonio Rivadeneira, uno de los escasos moderados históricos que presentaron su candidatura a obtener un acta $^{11}$. En su comunicado electoral no desaprovechó la oportunidad para despotricar contra sus antiguos compañeros de filas que habían abrazado el unionis$\mathrm{mo}^{12}$. Unos apóstatas difíciles de discriminar durante la campaña electoral a causa de la imprecisa terminología que destilan las fuentes para referirse a las distintas corrientes que desembocaron en el delta moderado.

La composición del Parlamento y, sobre todo, el inicio de la actividad parlamentaria, coadyuvaron a deslindar la adscripción política de los representantes. Baste recordar las veleidades unionistas explicitadas por Cándido Nocedal, a la sazón verdadero adalid de los neos, durante el desarrollo de la campaña electoral del verano-otoño de $1854^{13}$.

Varias iniciativas legislativas habría que destacar, por su relación con la génesis del corpus ideológico del neo-catolicismo, entre la ingente tarea legisladora desplegada por las volátiles Cortes de 1854-1856. La misma Cámara disuelta a cañonazos meses más tarde acogió las discusiones de proyectos que, no obstante su carácter testimonial, marcaron un antes y un después en la dialéctica de las relaciones Estado-Iglesia. Cuestiones como el debate en torno a la confesionalidad del Estado, la tolerancia de cultos o la libertad religiosa constituyeron verdaderos hitos, coronados por la reactivación de la acometida desamortizadora y la tensa ruptura de relaciones diplomáticas entre el Gobierno del duque de la Victoria y el Vaticano ${ }^{14}$.

El embrionario núcleo opositor neo-católico del Bienio se consolidó al calor de la contrarrevolución moderada y las sucesivas y partidistas reestructuraciones administrativas iniciadas durante el verano de 1856. El análisis del perfil biográfico de algunos de los nuevos cargos permite profundizar en el deslinde de la futura base social del neo-catolicismo. En Ciudad Real, la cascada de destituciones iniciada por O'Donnell abrió la puerta de entrada a moderados histó-

11 Y menos aún los que la obtuvieron, Víctor KIERNAN, La revolución de 1854 en España, Madrid, Aguilar, 1970, p. 121.

12 El Clamor Público, 30-IX-1854.

${ }^{13}$ Un breve perfil biográfico de Nocedal y un análisis de sus intervenciones en las Cortes del Bienio como azote, junto a los diarios precursores de la prensa neo-católica, de la política «secularizadora» impulsada por el Gobierno, en Begoña URIGÜEN, Orígenes y evolución..., op . cit., pp. 105-125.

${ }_{14}$ Resultan sugerentes al respecto los documentos vaticanos publicados por Franco DÍAZ DE CERIO y María Fe NúÑEZ MuÑoz, El bienio progresista (1854-1856) y la ruptura de relaciones de Roma con España según los documentos vaticanos, La Laguna, Universidad de La Laguna, 1993; no así las interpretaciones que ambos autores arrojan sobre la política del Gobierno de Espartero, un verdadero catálogo de dicterios contra las medidas secularizadoras impulsadas a lo largo de estos dos años.

Hispania Sacra, LX

121, enero-junio 2008, 297-329, ISSN: 0018-215-X 
ricos, como José Medrano, a insignes polacos, como Celedonio López o el sobrino de Fernando Chico, cuando no a declarados simpatizantes absolutistas como el marqués de Casa Treviño ${ }^{15}$. En octubre quedó completamente desvirtuado el equilibrio anhelado por el Duque de Tetuán entre las diferentes fuerzas políticas que a la sazón conformaron la amalgama unionista. Las tensiones generadas por su decidida intención de irrogar un nuevo impulso al proceso desamortizador y las presiones ejercidas por la influyente camarilla palaciega forzaron su defenestración. Y con él, una gran mayoría de los unionistas que todavía permanecían en las instituciones, en su práctica totalidad vicalvaristas, en beneficio del sector más conservador de los moderados ${ }^{16}$. Los repiques de campanas con los que fue recibido en Cuenca el encumbramiento del duque de Valencia puede considerarse la coronación simbólica de un proceso iniciado semanas atrás ${ }^{17}$.

Días antes la prensa ultramoderada había expresado con rotundidad y satisfacción la filiación política de aquellos en los que fueron a recaer los nuevos nombramientos, aquellos individuos que de una manera más o menos activa han pertenecido a las filas del gran partido conservador, impreciso magma en el cual entraron a formar parte desde los polacos, los moderados históricos y no pocos declarados absolutistas. En suma una heterogénea amalgama alejada de la imagen de unidad que se pretendió ofrecer por los diarios afines: se han bo-

15 José Medrano, tercer mayor contribuyente por contribución territorial de la provincia a la altura de 1863, ocupó la alcaldía de la capital en marzo de 1857 antes de obtener un escaño por idéntico distrito en las elecciones de 1863; AMCR, Libros de Actas del Ayuntamiento de Ciudad Real, 14-III1857, Boletín Oficial de la Provincia de Ciudad Real (en adelante BOPCR), num. 130, 14-X-1863. Celedonio López, Alcalde durante el mandato de San Luis, había sido expedientado por malversación de caudales públicos en 1854-1856, periodo durante el cual fueron destapados sus fraudes al frente del consistorio. El otrora principal defensor de la capital frente a las tropas de O'Donnell en 1854, fue designado en octubre de 1856 como Vicepresidente del repuesto Consejo Provincial, BOPCR, num. 210, 17-XI-1856. José María Chico, sobrino del linchado Jefe policial prerrevolucionario y uno de los símbolos de la polaquería, con las mismas tendencias que su tío, según un diario progresista, fue designado Guarda mayor del secuestro de D. Carlos en la provincia; El Clamor Público, 5-IX-1856. El marqués de Casa Treviño fue uno de los oficiales de la Milicia Nacional de la capital acusados de apoyar la causa absolutista durante las elecciones a oficiales celebradas en 1854; AMCR, Libros de Actas del Ayuntamiento de Ciudad Real, 28-X-1854. Durante el Sexenio ocupó la vicepresidencia de la Junta Católico-Monárquica de Ciudad Real, reducto del carlismo capitalino; véase Rafael VILLENA EsPINOSA, El Sexenio Democrático en la España rural. Ciudad Real (1868-1874), Ciudad Real, Instituto de Estudios Manchegos, 2006, pp. 317-330. Una condena de estos nombramientos, en La Discusión, 15$\mathrm{X}-1856$

16 Completando la secuencia del ejemplo ciudadrealeño, a mediados de octubre eran depuestos los últimos tres unionistas que todavía formaban parte del organismo provincial (Antonio García, José Domingo Maestre y Juan Laso). A partir de este momento los Monárquico-conservadores, según su propia denominación, dominaron la institución, una generalizante vitola bajo la cual se abrigaron declarados carlistas como Ramón Boada; BOPCR num. 194, 18-X-1856.

17 El Parlamento, 18-X-1856. 
rrado completamente las disidencias que entre aquellos produjeron las antiguas fracciones ${ }^{18}$. Por supuesto no tuvieron cabida los moderados y progresistas que habían integrado la coalición gubernamental en 1854, identificados por el Gobernador conquense con esas fracciones que habían disuelto los grandes $y$ legítimos partidos. Ocioso resultaría hablar de los demócratas.

Esta involución vino acompañada de unos señalados perfiles absolutistas, perceptibles al socaire de las sucesivas reestructuraciones administrativas, y marcada por un nítido componente de violencia política. A finales de 1856 el corresponsal del diario La Discusión en la localidad albaceteña de Villarrobledo trazó un agudo diagnóstico sobre la correlación de fuerzas existente en la provincia:

«Los efectos de la reparación, como se llama hoy a la ruina concreta del edificio constitucional, se han dejado sentir en esta provincia de un modo especial. La situación política que aquí se ha creado no responde a nada, es un mosaico en el cual las opiniones más opuestas se hallan confundidas y revueltas en una mezcla sin nombre. En el Consejo provincial brilla en todo su esplendor el astro absolutista, siguiéndole como humilde satélite algún moderado. La diputación es aquella misma que se amasó en tiempos de D. Leopoldo con sus dosis de monarquía pura, moderantismo y progreso; elementos que, por heterogéneos que parezcan, acertó a combinar la inteligente alquimia de la unión liberal... ¿Y qué diré a Vds. de la separación municipal? Nuestros correligionarios (los demócratas) han sido separados in totum; y como no había bastantes materiales moderado-religiosos para reconstruir el edificio, en casi todos los ayuntamientos han podido tener cabida algunos progresistas por vía de ripio para llenar los huecos. En fin la situación en esta provincia es un compuesto químico de doble base, en la cual entra la bula Ineffabilis como correctivo...»19.

Este perfecto mosaico descrito por el corresponsal demócrata para referirse al crisol de contendientes existente en la provincia de Albacete, perfectamente extrapolable al conjunto nacional, constituyó la situación de partida de la campaña electoral de marzo de 1857, si bien el verdadero clima involucionista que se vivió en algunas provincias como la de Cuenca hicieron incluso dudar de una próxima celebración de los comicios ${ }^{20}$.

Desde 1844 la política moderada había atraído a sus filas a numerosos simpatizantes de la causa contrarrevolucionaria que durante una década de granítica dominación permanecieron infiltrados en las nuevas instituciones represen-

${ }^{18}$ El León Español, 17-VIII-1856 y El Parlamento, 21-VIII-1856.

${ }^{19}$ La Discusión, 26-XII-1856.

${ }^{20}$ El Clamor Público, 14-XI-1856. En un artículo que el corresponsal conquense de este diario consagró a desmenuzar la trayectoria de los candidatos ministeriales a Cortes en la provincia llegó a poner en entredicho la futura celebración de las votaciones. Si bien no hay que obviar la recurrente dosis hiperbólica y subjetividad en la que incurrió la prensa, su relato no deja de constituir un indicio de ese ambiente pro-absolutista que marcó la precampaña electoral de 1857.

Hispania Sacra, LX

121, enero-junio 2008, 297-329, ISSN: 0018-215-X 
tativas ${ }^{21}$. Al abrigo del poder, una fracción significativa renunció a la vía insurreccional y se infiltró dentro del moderantismo ${ }^{22}$. El ascenso de Narváez en octubre supuso el regreso de una buena parte de la mayoría de los carlistas desplazados de la escena política de las cinco provincias castellano-manchegas durante los dos últimos años. Los ayuntamientos constituyeron los espacios de poder más tangibles y donde mejor se observa su encuadramiento en las instituciones representativas. Desde la prensa progresista se arremetió contra la renovación de algunos consistorios de la provincia de Cuenca con personas de opiniones absolutistas, moderado-absolutistas o rico-religiosos-realistas, según la peyorativa y vaga denominación impuesta a los contrarrevolucionarios conquenses desde los diarios opositores ${ }^{23}$.

Una reorganización político-administrativa emprendida en medio de un clima de crispación sociopolítica marcado por los registros, palizas e incluso asesinatos que sufrió un sector de los liberales que había ostentado el poder durante el Bienio ${ }^{24}$. Un ambiente pro-carlista que alcanzó cuotas extremas en algunas localidades con manifestaciones públicas abiertamente absolutistas ${ }^{25}$. En Tole-

\footnotetext{
${ }^{21}$ Desbordaría los objetivos de este trabajo detallar la infiltración de simpatizantes o antiguos carlistas en ayuntamientos, diputaciones, instituciones educativas durante la Década moderada o la propia Milicia Nacional entre 1854-1856 -por contradictorio que parezca- en las actuales provincias castellano-manchegas. Nos remitimos a mi tesis doctoral: Ciudadanos, propietarios y electores en la construcción del liberalismo español. El caso de las provincias castellano-manchegas, 1854-1868 (en prensa).

22 Proceso corroborado por diferentes especialistas en otras zonas de la península como Mallorca, Cantabria, Alicante, Zamora o Lleida; Pere FullanA, Mallorca durant el segle XIX (1808-1868), Palma de Mallorca, Documenta Balear, 1996, p. 40; Manuel EsTRADA SÁNCHEZ, La lucha por el poder. Derecho de sufragio y fraude electoral (Liébana 1834-1868), Santander, Parlamento de Cantabria/Ayuntamiento de Camaleño, 1999, pp. 73 y 95-101; Jesús MiLLÁN, El poder de la tierra. La sociedad agraria del Bajo Segura en la época del liberalismo, 1830-1890, Alicante, Instituto de Cultura «Juan Gil-Albert», 1999, pp. 85-90; José Luis OLLERO VALLÉs, El progresismo como proyecto político en el reinado de Isabel II: Práxedes Mateo Sagasta, 1854-1868, Logroño, Instituto de Estudios Riojanos, 1999, p. 63; y Josep María PONS I AltÉs, Moderats i progressistes a la Lleida del segle XIX (1843-1868), Lleida, Pagés editors, 2002, pp. 198-205.

${ }^{23}$ El Clamor Público, 16-XI-1856 y 11-XII-1856. En concreto dicha fuente se refiere, entre otras, a las localidades de Motilla, Villanueva de la Jara, Pizazo, Sisante, Valverde, Hinojosos, Casasimarro, Mota del Cuervo y Boniches.

24 Sin ánimo de exhaustividad, altercados de este tipo tuvieron lugar en las localidades conquenses de El Peral y Villanueva de la Jara, El Clamor Público, 24-XII-1856; en Ciudad Real, La Discusión, 15-X-1856; en Lillo (Toledo), La Discusión, 22-I-1857; en Villa de D. Fadrique (Toledo), El Clamor Público, 29-I-1857; en Torrijos (Toledo), El Clamor Público, 30-I-1857; en Albacete, Donde los moderados consecuentes han sido desdeñados por los prohombres de la situación que han encumbrado en el lugar que a los primeros correspondía a personas desconocidas en los partidos constitucionales, y que no disimulan su opinión contraria al régimen representativo, ni su fundada esperanza de una reacción más completa; La Discusión, 30-IV-1857; en Quintanar de la Orden (Toledo), La Discusión, 1-V-1857; y en Villarrobledo (Albacete), La Discusión, 26-VII-1857.

25 A tenor de los resultados obtenidos por la actividad insurreccional desplegada en las cinco provincias entre 1854-1856, donde fracasaron sucesivamente los esfuerzos por consolidar la rebelión (al-
} 
do, junto a los cánticos y agresiones a ex-milicianos, los simpatizantes carlistas, muchos de los cuales procedían del bando moderado, ostentaron públicamente por las calles de la capital las clásicas boinas que los absolutistas lucieron durante los periodos bélicos ${ }^{26}$.

Iglesia y prensa conservadora actuaron como instigadores en la gestación de la violencia política descargada contra progresistas y demócratas castellanomanchegos. Desde los voceros conservadores se ofreció una imagen de sosiego que poco se correspondió por ejemplo con el panorama conflictivo trazado para la capital y la provincia de Toledo. ¡Cuán lejos del idílico diagnóstico realizado desde las columnas del ultramoderado El Parlamento!:

«Este, país, donde mas que en otro alguno, las heces sociales puestas en fermentación por las circunstancias fueron ayudadas por las autoridades del gobierno, y donde la junta revolucionaria lejos de calmar las pasiones contribuyó a sobreexcitarlas por todos los medios imaginables, merece más que otro alguno fijar la atención de un gobierno que se proclama reparador y justo. El país hambriento de paz y de orden está tranquilo, sin hacer caso alguno de las noticiotas que los vencidos en julio reparten, con la sana intención que es de suponer. Justo es conceder este recurso único que les queda a los que tan ridículo alarde solían hacer de su fuerza y valor....en paradas, formaciones y motines» ${ }^{27}$.

Desde los púlpitos la violencia política contra progresistas y demócratas fue azuzada con intensidad, a partir 1856, como contrapartida a la reactivación de la desamortización y de la puesta en marcha de medidas secularizadoras entre 1854 y $1856^{28}$. En éstos términos de satisfacción se expresó el párroco de la lo-

zamientos caracterizados por su dispersión y cercenada operatividad), no resulta aventurado encuadrar a la región como una de las zonas de carlismo ideológico, pasivo o geográfico catalogadas por algunos autores para diferenciarlas de aquellos otros territorios donde realmente se puede hablar de un «país carlista», como Navarra, el País Valenciano, la Cataluña sur e interior, el bajo Aragón y el norte de Valencia, donde los sublevados si lograron consolidar una base territorial y administrativa a lo largo de las diferentes contiendas; Julio Aróstegui, Jordi Canal y Eduardo GonzÁlez CALleja, Las Guerras carlistas. Hombres, hechos e ideas, Madrid, La Esfera de los Libros, 2003, p. 146.

${ }^{26}$ El Clamor Público, 16-I-1857. No hay que menospreciar la capacidad de los símbolos, como es el caso de las boinas, para sublimar y condensar determinadas significaciones culturales que reforzaron la identidad común de un determinado colectivo -en este caso concreto dentro de la cultura política carlista- y de su capacidad para crear representaciones enfrentadas -a la liberal o a la republicana por ejemplo- durante las movilizaciones políticas; Rafael CRUZ, «La cultura regresa al primer plano», Rafael Cruz y Manuel PéRez Ledesma (eds.), Cultura y movilización en la España contemporánea, Madrid, Alianza, 1997, pp. 24-26; y Juan Sisinio PéREZ GARZÓN,»Curas y liberales en la revolución burguesa», en Ayer, 27 (1997), p. 86.

${ }^{27}$ El Parlamento, 1-XI-56.

${ }^{28}$ El púlpito, uno de los principales cauces de comunicación del Antiguo Régimen, fue sustituido por la prensa a lo largo de la etapa en cuestión. No obstante, el primero todavía retuvo un trascendental poder como vehículo transmisor y socializador de valores. Baste recordar la arenga política que un sacerdote de Valdepeñas dirigió a sus feligreses condenando la ideología democrática durante uno de sus sermones, La Democracia, 13-IV-1864. El periódico decimonónico surgió como un medio alternativo

Hispania Sacra, LX

121, enero-junio 2008, 297-329, ISSN: 0018-215-X 
calidad toledana de Torre de Esteban Hambrán a finales de 1856 para celebrar el nuevo momento político y el destronamiento del poder de aquel partido liberal del 54 que había salido del averno, cual el dragón infernal; pero que ya había vuelto a las profundas cavernas para no salir más ${ }^{29}$.

No hay que olvidar que durante el Bienio progresista el clero participó y se implicó como instigador e integrante de las partidas que se formaron en la actual Castilla La Mancha. Sirva como ejemplo la detención de un presbítero junto a la cúpula dirigente del complot desenmascarado para levantar en Albacete una partida en $1855^{30}$, o la porción de curas pertenecientes a la facción, que son los agentes más activos del carlismo implicados en la trama descubierta en Hinojosos (Cuenca), cuyos tentáculos condujeron hasta el mismo obispo de la diócesis:

«...la conspiración tenía también quien secundara sus planes en Zaragoza, Teruel y Cuenca...Es preciso tener en cuenta que la mayor parte de los sacerdotes de las diócesis de Cuenca, Teruel y Albarracín, pertenecieron a las filas de D. Carlos o fueron ordenados en Roma, durante la Guerra Civil, incluso el famoso padre Alcaraz, obispo de la primera diócesis que hemos citado» ${ }^{31}$.

Un amplio frente que abarcó desde la abierta participación de los eclesiásticos en insurrecciones contrarrevolucionarias al boicot de las nuevas medidas aprobadas por el ejecutivo esparterista a través de llamamientos a la desobediencia civil. Baste citar las órdenes dictadas por el Arzobispo de Toledo a sus canónigos prohibiéndoles entregar los bienes del clero subastados o formalizar los inventarios de los declarados de nuevo en venta en $1855^{32}$. La herida suturada por el Concordato en 1851 se abría de nuevo.

en manos de los nuevos grupos burgueses a estos cauces tradicionales de información, Francesc VALLS, Prensa y burguesía en el XIX español, Barcelona, Anthropos, 1988, pp. 12-14.

${ }^{29}$ La Iberia, 16-XII-1856; y El Clamor Público, 17-XII-1856.

${ }^{30}$ La Soberanía Nacional, 14-IX-1855.

${ }^{31}$ El Diario Español, 19-5-1855; y El Clamor Público, 20-V-1855. Las proclividades carlistas dentro de la jerarquía eclesiástica fueron más que excepciones, cuyo ejemplo más acabado vino de la mano de los antecedentes carlistas de fray Cirilo de Alameda, designado por Isabel II como primado de España y arzobispo de Toledo bajo la recomendación de sor Patrocinio y el confesor Claret; Emilio LA PARRA, «La reina y la Iglesia», Juan Sisinio Pérez GARZón, (ed.), Isabel II. Los espejos de la Reina, Madrid, Marcial Pons, 2004, pp. 202-203. La deriva carlista de la sede primada durante la primera contienda, en Manuel GutiérRez GarCía-BrazALeS, «Pedro González Vallejo, obispo liberal intruso en Toledo (1836-1842)», Actas del I Congreso de Historia de Castilla-La Mancha. Transformaciones burguesas, cambios políticos y evolución social, Toledo, Junta de Comunidades de Castilla-La Mancha, 1988, t. IX, pp. 233-240. Un denostado intento por minusvalorar, cuando no negar, las palmarias veleidades absolutistas de la jerarquía eclesiástica isabelina, en Francisco MARTí GILABERT, Iglesia y Estado en el reinado de Isabel II, Pamplona, EUNATE, 1996, en especial pp. 40 y 53.

${ }^{32}$ La Soberanía Nacional, 13-VII-1855. 
Sobre este sustrato marcado por la contrarrevolución moderada, imbuida por un clima de violencia política de acusada significación pro-absolutista, comenzó a enraizar el neo-catolicismo. Un grupo que, a tenor de los perfiles esbozados para el carlismo manchego, compartió con la tendencia absolutista importantes espacios de carácter ideológico y social ${ }^{33}$. La defensa de la Iglesia y del dogma católico ocupó un lugar axial en $\operatorname{ambos}^{34} \mathrm{y}$, por extensión, el clero y la jerarquía eclesiástica insuflaron un decidido apoyo numérico, ideológico y organizativo a uno y otro. La base social del neo-catolicismo se nutrió de un sector de las clases propietarias desgajado del Partido moderado, la misma formación en la que desembocaron o se infiltraron importantes elementos carlistas. No resulta aventurado presumir que éstos últimos, ante la falta de una alternativa política, que no llegaría hasta el Sexenio, brindasen su apoyo electoral a los primeros. No obstante estos espacios permeables, entre ambos también existieron fronteras bien definidas. Tras la «Gloriosa» el carlismo simultaneó la vía armada con la política, opción ésta última monopolizada por el neo-catolicismo durante el reinado isabelino. Su escudriñamiento aporta nuevas y decisivas claves para deslindar los contornos del grupo constituido a partir de 1854 .

\section{LA CONSTITUCIÓN DEL GRUPO NEO-CATÓLICO}

Controladas las diputaciones provinciales, tras la reparación operada entre los meses de julio y octubre, las elecciones municipales convocadas a unas semanas de los comicios a Cortes se presentaron para el Gobierno como la ocasión propicia para amarrar los ayuntamientos, biela decisiva de cara a controlar el desenlace de las generales y diagnosticar la correlación de fuerzas políticas existente ${ }^{35}$. A excepción de la capital albaceteña, donde triunfaron los progresistas, en el resto de capitales provinciales y en algunas cabezas de distrito la disputa se dirimió entre candidatos del Partido moderado. En concreto entre la fracción narvaísta o gubernamental y la incipiente tendencia neo-católica, denominada indistintamente como apostólica, monárquica pura

\footnotetext{
${ }^{33}$ No en vano Begoña URIGÜEN ha señalado que realistas y carlistas pertenecen a un mismo grupo, a una misma familia política; la que acabó por denominarse tradicionalista, y de la que forman parte tanto los realistas como los carlistas, los neo-católicos o integristas; en Orígenes y evolución..., op. cit., p. 51. Autora que también apuntó el respeto que se guardo al carlismo desde la prensa neo-católica y cómo durante el tramo final del reinado isabelino el grupo liderado por Nocedal trató de atraerse a la masa social absolutista, no obstante la equidistancia que el neo-catolicismo siempre guardó respecto al carlismo.

${ }^{34}$ Como apuntó Alexandra Wilhelmsen, La formación del pensamiento político del carlismo, Madrid, Actas, 1995, pp. 273-275.

35 Una revalorización de las secularmente denostadas elecciones municipales, en Concepción de CASTRO, La revolución liberal y los municipios españoles (1812-1868), Madrid, Alianza, 1979, p. 234.
}

Hispania Sacra, LX

121, enero-junio 2008, 297-329, ISSN: 0018-215-X 
o realista ${ }^{36}$. La indefinición de estas difusas denominaciones, allende corroborar el escaso grado de institucionalización del grupo neo-católico, atestiguan la dificultad existente en deslindar con claridad en el lenguaje de las fuentes las diferentes tendencias aglutinadas en el Partido moderado ${ }^{37}$. Una vaguedad terminológica también derivada del carácter peyorativo del término neo-católico, empleado con mayor profusión a partir de mediados de los sesenta precisamente por sus rivales políticos. En Guadalajara y Toledo, la victoria correspondió a los moderados gubernamentales o históricos, apelativo más genérico que no deslindó la importante deriva al neo-catolicismo que experimentaron los moderados de la capital toledana ${ }^{38}$. En Ciudad Real y Cuenca los nuevos ediles se repartieron entre moderados y realistas, con preponderancia de éstos últimos, una denominación que no explicitó el importante sector del clero que, como reconoció el ultracatólico El Parlamento, militó dignamente en el Partido moderado de la capital conquense ${ }^{39}$. Albacete constituyó la excepción a ésta panorámica general conservadora. El corresponsal demócrata de Villarrobledo ya adelantó la debilidad de los moderado-religiosos y del partido reaccionario en la provincia, circunstancia que había favorecido la entrada de los progresistas de orden en algunos ayuntamientos, asociados al ripio necesario para llenar los huecos dentro de la metafórica reparación del edificio constitucional operada durante la reacción moderada de $1856^{40}$. Como ya ocurriese en 1854 , los sugerentes resultados arrojados por las urnas resultaron clarificadores.

La crítica a la desamortización se había erigido como uno de los principales agentes aglutinadores de la corriente durante el mandato esparterista y la reacción moderada. Como ha señalado Martínez Gallego, el intento por irrogar un nuevo impulso privatizador constituyó uno de los principales puntos de fricción que motivaron la caída de O'Donnell en 1856 y aplazaron de forma transitoria la situación unionista ${ }^{41}$. De ahí que las invectivas vertidas contra las medidas desamortizadoras ocupasen un lugar central en la campaña electoral de 1857, verdadero referente movilizador e integrador del neo-catolicismo. Desde las columnas de La Esperanza, otro de los órganos del neísmo, se arremetió contra el administrador de Bienes Nacionales del partido de Molina de Aragón por haber ordenado al primer edil de Orea (Guadalajara) arrendar las tierras de la parro-

\footnotetext{
${ }^{36}$ Los resultados de las cinco capitales provinciales de la región y del resto peninsular, en El Diario Español, 18-II-1857.

37 Como han apuntado Javier Fernández Sebastián y Juan Francisco Fuentes, «A manera de introducción. Historia, lenguaje y política», Ayer, 53 (2004), p. 14.

${ }^{38}$ La Discusión, 28-X-1857.

${ }^{39}$ El Parlamento, 10-II-1857.

40 La Discusión, 26-XII-1856.

${ }^{41}$ Francesc Andreu Martínez Gallego, Conservar progresando: la Unión Liberal (1856-1868), Valencia, Instituto de Historia Social, 2001, pp. 35-36.
} 
quia subastadas durante el Bienio ${ }^{42}$. Sólo un ejemplo más. A comienzos de 1857 el primer edil neo-católico de Toledo mostró su satisfacción tras conocer la restitución parcial por parte del Gobernador Civil de una parte de los bienes de propios de la ciudad subastados a partir de 1855 que todavía no habían sido rematados ${ }^{43}$.

El arco de diputados elegidos en las cinco provincias castellano-manchegas ofreció un retrato prácticamente mimético de la composición de la nueva Cámara baja. La victoria de los candidatos gubernamentales en los distritos enfeudados de moderados históricos solo fue atemperada por las actas que obtuvieron algunos o'donnellistas y por el importante despegue cosechado por los neo-católicos al calor de la cartera de Gobernación detentada por Nocedal ${ }^{44}$. Los méritos atesorados durante el Bienio como azote de la política esparterista constituyeron la mejor carta de presentación a la hora de acceder a la decisiva atalaya ministerial. Un puesto desde el cual orquestó y dirigió los manejos electorales que facilitaron su elección por la capital ciudadrealeña ${ }^{45}$. El incipiente neo-catolicismo no renunciaba a ejercer la influencia moral en los procesos electorales que tan efectivos resultados había dado antaño a los moderados ${ }^{46}$. Unas coacciones que también coadyuvaron a facilitar la elección de correligionarios como Fernando Urríes en el distrito de Molina de Aragón (Guadalajara)

${ }^{42}$ La Esperanza, citado por El Clamor Público, 20-II-1857.

${ }^{43}$ El Clamor Público, 10-II-1857.

${ }^{44}$ Desbordaría los objetivos de este apartado detallar el resultado de las 37 actas electorales (ninguna de ellas fue a parar a manos progresistas). Para la consulta de los representantes electos, los detalles de la elección y el soporte documental, consúltese el apéndice documental de la tesis doctoral en fase de publicación ya mencionada.

${ }^{45}$ El Gobernador Civil de Ciudad Real llegó a desterrar de la capital al candidato opositor a Nocedal durante los días de la elección, el unionista Rafael Acedo Rico y Amat, irregularidades que no constan en el acta electoral: ACD, Series de Documentación Electoral, leg. 39, num. 11. Unos manejos que el conde de la Cañada denunciaría dos años más tarde desde su escaño en la primera legislatura del Gobierno Largo de O'Donnell; Diarios de Sesiones de Cortes, num. 28, 7-I-1859, p. 617. El militar y terrateniente o'donnellista había desplegado a escala provincial el papel desempeñado por el duque de Tetuán a nivel nacional durante el Bienio. En 1854 evitó que la revolución desembocase en cauces democráticos, reprimió los motines que estallaron en la provincia y dirigió la contrarrevolución moderada de 1856. El conde de la Cañada constituyó un verdadero candidato arraigado en el distrito, con numerosos méritos sacrificados en el altar del orden y respaldado por el apoyo de los muy influyentes linajes de los Medrano -sus parientes-, los Maldonado y los Muñoz, tres de las familias más poderosas no sólo de la capital sino de toda la provincia; La Discusión, 24-III-1857. Una suma de elementos que explica las dificultades y los fraudulentos manejos a los que tuvo que recurrir el Gobierno para lograr doblegarlo, posiblemente la causa que empujó a Nocedal a optar por otro de los distritos en los que también resultó elegido.

${ }^{46}$ En relación al eufemismo utilizado para denominar la injerencia gubernamental en las elecciones, véase L. M. PASTOR: La política que expira y la política que nace, Madrid, Imprenta de M. Galiano, 1860; y del mismo autor, Las elecciones, sus vicios. La influencia moral del Gobierno. Estadísticas de la misma y proyecto de reforma electoral, Madrid, Imp. M. Galiano, 1863.

Hispania Sacra, LX

121, enero-junio 2008, 297-329, ISSN: 0018-215-X 
y de los seis diputados neo-católicos por Toledo ${ }^{47}$, provincia en la cual se articuló, hasta el final mismo del reinado isabelino, uno de los verdaderos bastiones del neo-catolicismo en torno a la influencia numérica, ideológica y organizativa irradiada por la sede arzobispal. No resulta baladí que León Carbonero y Manuel Cañete, directores de los diarios afines El Parlamento y La Cruz optasen a un acta por Toledo en 185748 .

Formar parte de la redacción de uno de estos periódicos se erigió en uno de los medios idóneos para afianzar una carrera política o alcanzar un puesto en las constantes remodelaciones partidistas a que fue sometida la administración. Constituye una buena muestra el nombramiento en 1857 de Esteban Garrido como Gobernador Civil de Toledo, antiguo compañero de redacción de Cándido Nocedal en el periódico El Padre Cobos, publicación precursora de la prensa neo-católica durante el Bienio progresista ${ }^{49}$.

Sería un error desdeñar o minusvalorar el papel que jugó la sociabilidad informal en la configuración del bastión neo-católico toledano ${ }^{50}$. Lo demuestra la reunión celebrada por esa fracción con motivo del funeral del Arzobispo de Toledo durante la precampaña de 1857, exequias que sirvieron para explicitar fidelidades políticas, ideológicas y electorales ${ }^{51}$. Tampoco resulta baladí la fecha que escogió Cándido Nocedal para realizar una visita a la capital toledana, el 25 de octubre de 1857, tan sólo unos días después de haber caído el ministerio presidido Narváez y se especulaba con una posible convocatoria de nuevas elecciones ${ }^{52}$.

Un Gobierno que desde un primer momento había sido presa de la inestabilidad causada por la descomposición del Partido moderado en múltiples frac-

\footnotetext{
${ }^{47}$ En concreto, resultaron electos Manuel Bertrán de Lis por Talavera de la Reina (aunque al igual que Cándido Nocedal optó por otro distrito); Manuel Adoración García Ochoa por Navahermosa; Manuel María Herreros en Madridejos; Valentín Maroto por Torrijos; Miguel María Melgar por el distrito de Lillo; y el conde de Vilches por la capital provincial.

${ }^{48}$ El Diario Español, 10-II-1857 y 22-II-1857.

${ }^{49}$ La Discusión, 28-X-1857. Como ha señalado Begoña Urigüen, El Padre Cobos trazó las líneas de la incipiente prensa neocatólica a partir de 1854: critica al partido en el poder, defensa de los intereses de la Iglesia y de las personas eclesiásticas, sumisión a la Corona y respeto por el carlismo; Orígenes y evolución de la derecha..., op. cit., p. 114.

${ }^{50} \mathrm{Y}$, como ha señalado Artola, un pragmático medio de sortear la férrea censura a la que tuvo que hacer frente la oposición a la hora de organizar reuniones políticas a lo largo del periodo isabelino, en Partidos y programas políticos, 1808-1936. I. Los partidos políticos, Madrid, Alianza, 1991, p. 164.

${ }^{51}$ La España, 24-II-1857.

${ }^{52}$ La Discusión, 28-X-1857. Las intenciones del respetabilísimo y religioso ex-ministro no pasaron por alto para el avispado corresponsal del diario de Pi i Margall en Toledo, recibido por las autoridades locales a las afueras de la ciudad con una acogida de carácter prácticamente oficial. Entre ellas figuraron los ya citados Gobernador y Alcalde de Toledo, el Juez de primera instancia y un Consejero provincial, es decir, la que podría catalogarse como la cúpula neocatólica de Toledo en 1857.
} 
ciones, algunas de ellas, como ocurrió con los neo-católicos, paradójicamente más cercanas a posiciones involucionistas que a razonamientos situados dentro del marco liberal. Las expresiones más diáfanas de estas oscilaciones tuvieron reflejo en la reaccionaria Ley de Reforma Constitucional -iniciativa de similares características al proyecto bravomurillista de 1852 - y en el soterrado intento de reposición de los mayorazgos a través de la Ley de Vinculaciones ${ }^{53}$. Unas propuestas que, pese a no ser rechazadas formalmente -de hecho entraron en un largo periodo de impasse- no hicieron sino ahondar en la sima abierta en el seno del moderantismo ${ }^{54}$. De hecho ambas iniciativas aspiraron a establecer una doble cerrazón política y económica cuya ratificación habría supuesto extender una losa sobre la apenas hollada mina de la desamortización. Unas iniciativas que no fueron sino reflejo de una incertidumbre explicitada con anterioridad a la formación de la Cámara Baja:

«...la gran mayoría de este pueblo liberal espera con ansia la apertura de las Cortes, no porque de ella se prometa ventaja alguna en la situación política, sino por comprender todos que necesariamente ha de cesar la incertidumbre en que vivimos respecto a las tendencias que predominan en las altas esferas del Gobierno...Los moderados consecuentes han sido desdeñados por los prohombres de la situación que han encumbrado en el lugar que a los primeros correspondía a personas desconocidas en los partidos constitucionales, y que no disimulan su opinión contraria al régimen representativo, ni su esperanza de una reacción más completa».

«Se aguarda con impaciencia la constitución del Congreso que hasta hoy no es más que un campamento sembrado de grupos. Estos grupos son otras tantas pilar de volta. ¿Hacia que polos refluirá tanta electricidad?» ${ }^{55}$.

Ambos testimonios, confeccionados a partir del sentir latente entre el arraigado progresismo de la capital albaceteña, resultan reveladores del incierto clima político y explican la zigzagueante trayectoria que acompañó al Gobierno de Narváez merced a la endeblez de su base de apoyo. También preludiaron la ruptura con el liberalismo que preconizará la fracción neo-católica a mediados de los sesenta. Los transitorios ministerios de Armero e Istúriz no hicieron sino constatar que la electricidad mencionada en el fragmento anterior estaba encaminada hacia la experiencia unionista, con dos claras pilas de volta o fuentes de energía: los progresistas de orden y los moderados puritanos o vicalvaristas.

\footnotetext{
${ }^{53}$ La tarea legislativa acometida por el unionismo, en Nelson DURÁn DE LA RUA, La Unión Liberal y la modernización de la España isabelina. Una convivencia frustrada, 1854-1868, Madrid, Akal, 1979.

${ }^{54}$ Como señaló José María Jover, Política, diplomacia y humanismo popular en la España del siglo XIX, Madrid, Turner, 1976, p. 325.

${ }^{55}$ La Discusión, 30-IV-1857 y 8-V-1857.
}

Hispania Sacra, LX

121, enero-junio 2008, 297-329, ISSN: 0018-215-X 


\section{EL LARGO ECLIPSE UNIONISTA}

La reelaboración de las listas por parte del incipiente ejecutivo unionista implicó automáticamente el castigo del adversario político. Las críticas llovieron desde los órganos periodísticos de las oposiciones, y, particularmente, desde los diarios de la liga blanca, sobrenombre con el que se había denominado a los periódicos, como La España, afectos al último Gobierno de Narváez. Ni un solo conservador resulta en ellas, se denunció desde sus columnas -sin menospreciar la recurrente dosis hiperbólica- a propósito de la rectificación de las listas de electores en Cuenca, Guadalajara y Toledo ${ }^{56}$. La vinculación de esta plataforma periodística con la fracción neo-católica quedó de manifiesto con motivo de las críticas vertidas contra los candidatos resellados que habían defendido durante el Bienio la Base segunda del proyecto de Constitución, disposición que estipuló la libertad de práctica de credos religiosos:

«Imposible es, en verdad, olvidar aquel no lejano bienio en que las cortes constituyentes, hijas de la revolución, confeccionaron un golpe terrible para nuestra religión, fundamento principal, como preciso es reconocer, del buen orden social, y por lo tanto de la prosperidad nacional...La famosa base segunda que descargaba aquel golpe...fue causa del destierro de algunos ilustrísimos obispos...Sin embargo no faltaron constituyentes que prestaron su apoyo a la misma base...que hoy aparecen nuevamente y con pretensiones de conseguir por todos los medios la representación de este país...» ${ }^{57}$.

Los demonizados aspirantes arriacenses aludidos no fueron los únicos. El candidato progresista por la capital toledana, el también resellado Ambrosio González, fue estigmatizado por la misma razón que sus correligionarios de Guadalajara: haber sostenido in illo tempore la Base segunda. Un recurso, la utilización de la religión como arma política, al que volvieron a recurrir los neo-católicos como mejor forma de presentar a su líder y candidato opositor: Cándido Nocedal, el defensor de la unidad religiosa ${ }^{58}$. Posada Herrera fue

\footnotetext{
${ }^{56}$ La España, 19-IX-1858. En el caso de la provincia de Ciudad Real se denunció que el número inclusiones y exclusiones con carácter partidista había ascendido a una cifra total cercana a los tres millares; El Diario Español, 17-IX-1858. Desde el extremo opuesto, la prensa demócrata también censuró, aunque con un menor énfasis, la inhibición del censo electoral. La remodelación no había afectado a sus correligionarios con la incidencia que salpicó a los moderados, quines sólo unos meses antes habían moldeado las listas a su antojo. Un correligionario de Almagro clamó contra las rectificaciones realizadas en dicha localidad, censuró la inclusión en las listas a personas fallecidas y la eliminación de ellas de electores de pleno derecho; Tengo el honor de ser un superviviente y gracias por mi parte a la administración, aunque tenga que llorar la pérdida de mis compañeros fallecidos; La Discusión, 1-X1858.

57 El Parlamento, 5-X-1858. En concreto se hizo una explícita referencia a los candidatos Diego García, José Medrano y Ramón Ugarte.

${ }^{58}$ Begoña UrigüEn, Orígenes y evolución..., op. cit., p. 129.
} 
consciente del potencial movilizador y coactivo que el clero toledano con el Cardenal primado a su cabeza fue capaz de desplegar en las luchas electorales. ¿Qué mejor indicador que las seis actas electorales que el neo-catolicismo obtuvo en las elecciones celebradas en la provincia en 1857! De ahí que instase en 1858 al Gobernador Civil de Toledo a intensificar las manipulaciones a favor del candidato ministerial, su sobrino Pérez Caballero y Posada, con el objetivo de doblegar a Cándido Nocedal y neutralizar el soporte proporcionado por el cabildo catedralicio, apoyo que le había permitido forzar la convocatoria de segundas elecciones en el distrito capitalino:

«Mi estimado amigo, dos confidentes de confianza me confirman que el Arzobispo de Toledo y el clero trabajan decididamente por D. Cándido Nocedal. Ya sabe V. que el candidato del Gobierno es allí una persona de ideas religiosas que reúne las simpatías de la población. Esto hace más injustificable semejante conducta. Ruego a V. tenga la bondad de hacer lo que sea posible para que en las segundas elecciones que están tan próximas, no tengamos que luchar también contra tan grave inconveniente» ${ }^{59}$.

La trascendencia que en la correspondencia cruzada entre las autoridades gubernamentales se otorgó a la concurrencia y alineación electoral del clero levantó acta de su decisiva capacidad de llamada y compulsión ${ }^{60}$. Constituyó un inconveniente equiparable a la resistencia ofrecida por un candidato opositor con arraigo en el distrito. Constituiría un error minusvalorar esta estrategia como uno de los principales elementos movilizadores durante la campaña electoral y su decisiva influencia en el encauzamiento del voto ${ }^{61}$. Baste recordar el interés

${ }^{59}$ Archivo Histórico Provincial de Asturias (en adelante AHPAS), Fondo Posada Herrera, caja 11.378, leg. 6, num. 2 .

${ }^{60}$ Como ha señalado Pere Anguera, el tradicionalismo utilizó a la Iglesia y la defensa de sus intereses como un elemento clave en la propaganda política, en «El liberalismo desde el tradicionalismo», Manuel SuÁrez Cortina (ed.), Las máscaras de la libertad. El liberalismo español, Madrid, Marcial Pons/Fundación Práxedes Mateo Sagasta, 2003, p. 269.

${ }^{61}$ La influencia e intervención de los eclesiásticos en las luchas electorales decimonónicas ha sido detectada por diversos especialistas, desde los primeros pasos de la andadura liberal, La Parra, E.: «Oposición constante y sistemática: la Iglesia católica y el poder civil en el inicio de la revolución liberal en España», Emilio LA PARRA y Germán RAMíREz (eds.), El primer liberalismo: España y Europa, una perspectiva comparada, Valencia, Actas, 2003, pp. 137-154; la minoría de edad de la soberana, Carlos Marichal, La revolución liberal y los primeros partidos políticos en España, Madrid, Cátedra, p. 189; durante el reinado isabelino, Xose Ramón BARREIRo FERnÁNDEZ, «Las elecciones de la Unión Liberal (1858) en la provincia de Ourense y el tema del caciquismo», 1 Xornadas de Historia de Galicia, Ourense, Deputación, 1985, p. 77; y Margarita CABALLERo Domínguez, El Sufragio censitario. Elecciones generales en Soria durante el reinado de Isabel II. Ávila, Junta de Castilla y León, 1994, pp. 138-141, 209 y 284-286; el Sexenio, Xose Ramón VeIGa Alonso, O conde de Pallares Pallares e o seu tempo, 1828-1908. Aproximación ó activismo das elites na Galicia decimonónica, Lugo, Deputación Provincial, 1999, pp. 213-214; o la Restauración, José María BARREDA FonTES, Caciques y electores. Ciudad Real durante la Restauración, 1876-1923, Ciudad Real, Instituto de Estudios Manchegos, 1986, pp. 368-371; Luis CASTELls, Modernización y dinámica política en la sociedad guipuzcoana de

Hispania Sacra, LX

121, enero-junio 2008, 297-329, ISSN: 0018-215-X 
de la prensa progresista por ensalzar el fervor religioso del candidato resellado toledano tras colocarse la cuestión electoral en el terreno religioso ${ }^{62}$. De éste potencial fue consciente el Gobernador de Ciudad Real cuando ordenó, previo acuerdo con el vicario eclesiástico, reunir en la capital ciudadrealeña a varios frailes secularizados del distrito de Malagón que estaban tomando parte activa en la lucha electoral a favor del candidato de oposición, presentando como un hereje al aspirante ministerial ${ }^{63}$. El todopoderoso Jefe político provincial supo advertir el riesgo de que la labor desplegada por dichos clérigos echase por tierra todos los trabajos preparatorios orquestados por la maquinaria electoral gubernamental. Aquilata la hipótesis planteada la mención de la influencia ejercida por curas párrocos sobre el electorado en algunas de las actas más disputadas de la etapa isabelina ${ }^{64}$. También la participación directa de algunos eclesiásticos en la articulación de las redes caciquiles locales, como atestigua la petición que el párroco de El Toboso elevó a Posada Herrera para que nombrase alcalde y teniente a dos amigos recientemente designados concejales ${ }^{65}$.

la Restauración, 1876-1915, Madrid, Siglo XXI-Universidad del País Vasco, 1987, p. 280; Ángel GARCía-SANZ MarCotegui, Caciques y políticos forales: las elecciones a la Diputación de Navarra (18771923), Pamplona, Esquiroz, 1992, pp. 367-370; y José VARela OrTEGA, Los amigos políticos. Partidos, elecciones y caciquismo en la Restauración (1875-1900), Madrid, Alianza, 1977, p. 394. Una influencia similar que creció en el conjunto de Italia tras el proceso de unificación, Franco ANDREUCCI, «La norma e la prassi. Le elezioni irregolari nell'Italia liberale (1861-1880)», Passato e presente, 34 (1995), p. 68.

${ }^{62}$ La Discusión, 28-X-1858. Como así reseña el diario demócrata, ésta fue la estrategia que siguió El Clamor Público para apoyar a su aspirante.

${ }^{63}$ El Diario Español, 28-X-1858.

${ }^{64}$ El Comité de Unión Liberal de Cuenca denunció la influencia que en el ánimo de los electores, ejerció el cura párroco de Albaladejo del Cuende, junto a otra serie de funcionarios y diputados provinciales, durante las segundas elecciones celebradas en el distrito de la capital en 1864 que finalizaron con la victoria del moderado neocatólico Severo Catalina; AHPAS, Fondo Posada Herrera, caja 11.406, leg. 34, num. 40. Más contradictorio resultó, por la propia filiación progresista de Venancio González, el apoyo que algunos eclesiásticos del distrito de Lillo prestaron a este candidato en 1863 , decisivo en su apretada victoria (decidida por un voto de diferencia). Es el caso de la denuncia presentada ante la Comisión de actas contra el cura de Villarrubia por haber recorrido varias casas de esta localidad violentando a los electores, y contra el Vicario eclesiástico de Ocaña por acompañar al Gobernador en su recorrido por la circunscripción amenazando a los electores del aspirante opositor; ACD, Series de Documentación Electoral, leg. 49, num. 6. El apoyo del clero a este candidato progresista debió responder a su arraigo en el distrito o a una posible vinculación familiar con los religiosos, causas similares a las que movieron al Obispo de Osma a brindar apoyo electoral al «puro» Ruiz Zorrilla en este distrito en 1858 ensalzando la vecindad y fortuna del candidato (que no se explican sin tener en cuenta las vinculaciones personales entrambos -era su padrino de boda- y la actitud beligerante del prelado hacia el Gobierno de O'Donnell); Margarita CABALLERO, El Sufragio censitario..., op . cit., pp. 284-286. Un proceso similar tuvo lugar en las elecciones celebradas en 1858 en Bande (Orense) a raíz de las vinculaciones familiares que ligaron a un eclesiástico y uno de los candidatos a Cortes, en Xose Ramón BARREIRO FERNÁNDEZ, «Las elecciones de la Unión Liberal...», op. cit., p. 77.

${ }^{65}$ AHPAS, Fondo Posada Herrera, caja 11.378, leg. 6, num. 2. José Maiz Bailena, hermano político del párroco, actuó de intermediario ante su amigo el Ministro de la Gobernación. 
El neo-catolicismo, pese a la hostilidad de las autoridades, se consolidaba en la provincia de Toledo al cobijo de la sombra proporcionada por la sede arzobispal. La concurrencia de un candidato por todos y cada uno de sus distritos constituye la prueba más palpable ${ }^{66}$. Ni siquiera en la última cita electoral cuando contaron con la anuencia del Gabinete Narváez-Nocedal había desplegado tal grado de movilización. El propio Cardenal primado fue acusado desde el oficialista El Clamor Público de hacer campaña electoral a favor del paladín del neís$m o^{67}$. No resulta aventurado presuponer la elección de Cándido Nocedal de no haberse topado en el distrito toledano con José Pérez Caballero y Posada, sobrino del «Gran elector». Una hipótesis contrafactual en absoluto aventurada si se desentraña detenidamente el acta electoral, donde el empate casi técnico de la primera votación obligó a celebrar una segunda vuelta en la que las irregularidades electorales doblegaron al religioso candidato ${ }^{68}$. En esta ocasión, resultaron plenamente justificadas las reclamaciones vertidas desde las columnas del ultracatólico El Parlamento que achacaron a la influencia moral la derrota sufrida por su paladín y el resto de aspirantes en el emporio del neo-catolicismo ${ }^{69}$.

\section{Del ostraCisMo Al ACTIVISMO NEO-CATÓLICO}

La estabilidad gubernamental, que había presidido los cinco años de mandato del duque de Tetuán, dieron paso a partir de 1863 a un lustro marcado por la inestabilidad política, con continuos cambios ministeriales que respondieron a las disputas internas entre distintas fracciones dentro del doctrinarismo. Paralelamente se incubó un proceso de polarización política que tuvo como protagonistas a los dos extremos del arco político. Puros y demócratas optaron decididamente por la abstención dentro de un horizonte revolucionario. En el extremo opuesto, el fortalecimiento de las posiciones ultraconservadoras lideradas por los neo-católicos constituyó el contrapunto autoritario al crecimiento experimentado por las fuerzas de la «revolución». La dimisión de O’Donnell en febrero de 1863, a causa de las disputas intestinas abiertas en el seno de su coalición, inauguró una etapa en la que la confianza de la Reina recayó

${ }^{66}$ La España, 13-VIII-1858.

${ }^{67}$ El Clamor Público, 7-XI-1858.

${ }^{68} \mathrm{ACD}$, Series de Documentación Electoral, leg. 45, num. 10. En la primera vuelta Cándido Nocedal llegó incluso a superar en sufragios al candidato ministerial -con 169 votos-frente a los 165 de Pérez Caballero y Posada y las 162 papeletas del progresista Rodrigo González Alegre. En segundas elecciones se redoblaron las manipulaciones para rebasar al antiguo Ministro de la Gobernación. El propio Nocedal escribió un opúsculo en el cual, además de despotricar contra las autoridades, desglosó los manejos orquestados para zancadillear su elección: Las actas de Toledo, representación dirigida al Congreso de los Diputados, Madrid, Imp. Rivadeneyra, 1858.

${ }^{69}$ El Parlamento, 13-XI-1858.

Hispania Sacra, LX

121, enero-junio 2008, 297-329, ISSN: 0018-215-X 
indistintamente en moderados y unionistas en una suerte de «turnismo» operado dentro de los límites del campo conservador.

Desde 1863 la dialéctica entre un mermado unionismo y unos moderados relativamente reconfortados giró en torno a los guiños de los primeros por atraerse a los elementos menos exaltados del progreso, a través de iniciativas como la Ley Cánovas de prensa de 1864 o la normativa electoral de 1865, frente a la deriva autoritaria y represiva experimentada por los segundos, más reacios a extender la estrecha base de apoyo de la Monarquía constitucional de Isabel II. En común, el miedo a la revolución encarnada por los abstencionistas progresistas y demócratas, cuyo crecimiento y organización en la región y el conjunto peninsular no dejaron menguar aún después de haber renunciado a participar en las consultas electorales ${ }^{70}$.

Tras el largo eclipse unionista, los neo-católicos recuperaron amplias cuotas de influencia al calor de las fluidas relaciones que sus principales dirigentes mantuvieron con destacados miembros del Gobierno. Las estrechas vinculaciones que unieron a Cándido Nocedal con el Ministro de la Gobernación, Rodríguez Vaamonde, constituyen una buena muestra ${ }^{71}$. Y, de nuevo, el foco toledano a la cabeza, por cuya capital repitió candidatura el primero de ellos:

«La gente neocatólica se va envalentonando. Verdad es que todo concurre a que crezca su importancia y su prestigio: porque mientras los demás partidos se andan por los cerros de Úbeda, ellos trabajan mucho, están bien organizados y encuentran protección en las regiones oficiales para ciertos hombres y ciertas cosas» 72 .

El testimonio recobra todavía mayor valor y credibilidad si se tiene presente que procede de un diario en absoluto sospechoso de conjugar con sus doctrinas, sino precisamente del vocero que de forma más severa y contundente se distinguió, desde sus comienzos y hasta la censura de la publicación en 1866, en desacreditar esta tendencia.

Baste recordar los peyorativos de furibundo demagogo y rabioso neo que dedicaron los corresponsales toledanos en sus crónicas electorales para referirse a Cándido Nocedal ${ }^{73}$. O el bando municipal que el Alcalde neo-católico de

\footnotetext{
${ }^{70}$ Cómo puse de manifiesto en otro trabajo, «¿Demócratas en La Mancha? En torno a los orígenes de la cultura política republicana en Castilla-La Mancha», en Espacio, Tiempo y Forma, Serie V, Historia Contemporánea, t. 18 (2006), pp. 111-133.

${ }^{71}$ Como ha señalado Xose Ramón Veiga Alonso, los fluidos contactos con miembros del Ejecutivo central resultaron decisivos a la hora de afrontar las luchas electorales y de satisfacer las aspiraciones de las clientelas políticas de los notables locales, en «Los marcos sociales del clientelismo político», Historia Social, 34 (1999), pp. 27-44.

${ }^{72}$ El Pueblo, 10-VII-1863.

${ }^{73}$ El Pueblo, 10-X-1863.
} 
Toledo publicó a la altura de 1865 prohibiendo la venta de todo artículo que no fuese comestible a partir de las nueve de la mañana de los días festivos -hora en que salía la prensa a la calle- en un intento, según los demócratas de la localidad, de restringir en la ciudad la difusión del diario El Pueblo, que tanto disgusta a la gente de sotana ${ }^{74}$.

El oxígeno insuflado por el Gobierno coadyuvó innegablemente a la reorganización de sus redes clientelares sin otro horizonte que las elecciones. Los sucesivos nombramientos en puestos clave de la administración provincial recayeron en miembros de la clientela política del promotor de la represiva Ley de prensa de 1857. Precisamente fue el candidato opositor, Pérez Caballero y Posada, quien denunció en la prensa, en un depurado ejercicio de cinismo político, los mismos mecanismos que cinco años atrás había empleado su tío, Posada Herrera, a su favor ${ }^{75}$.

Los resultados electorales a Cortes ratificaron las pautas trazadas para la campaña electoral. El Gobierno había obtenido una clara y abrumadora mayoría que, en la región, adquirió perfiles bien concretos. A los inamovibles moderados históricos se unieron nuevos hombres que ocupaban por primera vez un escaño tras el paréntesis unionista, caras nuevas, fruto del proceso de «recomposición» del Partido moderado. A su derecha obtuvieron escaño los neo-católicos Cándido Nocedal y Manuel María Herreros por la capital y el distrito toledano de Navahermosa, respectivamente. Con inclinaciones o apoyados por los neo-católicos de algunos distritos resultaron elegidos el conde de Vilches por Madridejos; José García Gutiérrez por Elche de la Sierra; Severo Catalina por Alcázar de San Juan; Juan Bautista Trúpita por la capital conquense e Isidoro Ternero por la de Guadalajara. La corriente se afianzó definitivamente. La ampliación de su radio de influencia más allá de Toledo lo prueban palpablemente.

El desmenuzamiento de los censos electorales permite visualizar con nitidez algunas de las claves de su afianzamiento electoral ${ }^{76}$. Se han examinado los censos municipales de Guadalajara, Toledo y Cuenca, las tres capitales provinciales por cuyos distritos obtuvieron representación los candidatos neo-católicos en $1863^{77}$. A diferencia de su homóloga moderada a Cortes, la ley electoral municipal de 1845 estipuló una masiva incorporación de las capacidades al censo,

\footnotetext{
${ }^{74}$ Ibidem, 14-II-1865.

${ }^{75}$ El Diario Español, 1-X-1863. Al margen del trascendental apoyo electoral del Gobernador Civil, previamente habían sido sustituidos el presidente del Consejo Provincial, un vocal de la Junta Provincial de Beneficencia o el propio cargo de Alcalde, puestos que fueron a recaer a manos de Víctor Martín, Antonio Acebedo y Manuel María Herreros, personas notoriamente afectas al candidato.

${ }^{76}$ Las normativas electorales vigentes durante el periodo isabelino, en Manuel EsTRADA SÁNCHEZ, El significado político de la legislación electoral en la España de Isabel II, Santander, Universidad de Cantabria, 1999.

77 A pesar de que los censos corresponden al año 1860, el escaso crecimiento poblacional experimentado hasta 1863 no supuso ninguna variación significativa en los porcentajes arrojados.
}

Hispania Sacra, LX

121, enero-junio 2008, 297-329, ISSN: 0018-215-X 
propiciada por la eliminación de los restrictivos requisitos pecuniarios exigidos a las inteligencias a nivel estatal (un $27.1 \%$ del total del electorado en Cuenca, un $23.6 \%$ en Guadalajara y un $33.8 \%$ en Toledo). La nada desdeñable representación de los eclesiásticos en el constrictivo censo municipal, sobremanera en Cuenca y Toledo, un $31.08 \%$ y un $26.47 \%$ sobre el total de las inteligencias, puede explicar el encauzamiento y dirección del voto en ambas sedes eclesiásticas. Trayectorias de electores como Antolín Monescillo ${ }^{78}$ ciudadano activo en el censo municipal toledano en 1860 en calidad de canónigo del cabildo catedralicio, resultan harto esclarecedoras de la orientación política de los eclesiásticos:

CuADRo I: Distribución de los electores capacidades en los censos municipales de Cuenca, Toledo y Guadalajara según la ley municipal de 1845 (1860)

\begin{tabular}{|l|l|c|c|c|}
\hline \multicolumn{2}{|l|}{ Electores capacidades } & Cuenca & Guadalajara & Toledo \\
\hline Eclesiásticos & $23(31.08 \%)$ & $5(8.19 \%)$ & $54(26.47 \%)$ \\
\hline Empleados de la Administración & $11(14.86 \%)$ & $16(26.22 \%)$ & $33(16.17 \%)$ \\
\hline \multirow{2}{*}{$\begin{array}{l}\text { Profesionales } \\
\text { liberales }\end{array}$} & $\begin{array}{l}\text { Jueces y fiscales } \\
\text { Médicos, } \\
\text { farujanos y }\end{array}$ & $1(1.35 \%)$ & $2(3.27 \%)$ & $1(0.49 \%)$ \\
\cline { 2 - 5 } & $\begin{array}{l}\text { Catedráticos, } \\
\text { profesores y } \\
\text { maestros }\end{array}$ & $14(18.91 \%)$ & $17(27.86 \%)$ & $8(3.92 \%)$ \\
\cline { 2 - 6 } & Abogados & $9(12.16 \%)$ & $6(9.83 \%)$ & $6(2.94 \%)$ \\
\hline \multicolumn{2}{|l|}{ Oficiales militares retirados } & $10(13.51 \%)$ & $22(36.06 \%)$ & $88(43.13 \%)$ \\
\hline \multicolumn{2}{|l|}{ Total } & $74(27.1 \%)$ & $61(23.6 \%)$ & $204(33.8 \%)$ \\
\hline
\end{tabular}

Fuente: elaboración propia ${ }^{79}$

78 Sobre la biografía y trayectoria política de Antolín Monescillo, véanse los diferentes trabajos recogidos en Francisco Alía Miranda y Antonio DE JUAN (coords.): «El Cardenal Monescillo: vida y obra», Centenario del Cardenal Monescillo (1897-1997), Cuenca, Universidad de Castilla-La Mancha/Cortes de Castilla-La Mancha/Ayuntamiento de Corral de Calatrava, 1997, vol. I; los condescendientes retratos biográficos elaborados por Rafael María SANZ DE DIEGO, «Antolín Monescillo y Viso (1811-1897), cardenal de La Mancha», en Actas del I Congreso de Historia de Castilla-La Mancha, op. cit., vol. IX, pp. 255-261; y Bernardo VIllazÁN, Ensayo biográfico del Cardenal Monescillo, Ciudad Real, 1962, separata de Cuadernos de Estudios Manchegos; y el análisis de su protagonismo político tras la «Gloriosa» como diputado carlista realizado por Rafael VillenA EsPINOSA, El Sexenio Democrático en la España rural..., op. cit., pp. 336-338 y 384.

${ }^{79}$ Los valores de la capital conquense, en Archivo Municipal de Cuenca (en adelante AMUCU), 
El proceso de polarización política, iniciado en 1863, no se interrumpió en 1864. El neo-catolicismo toledano aprovechó el ínterin existente entre los periodos electorales para fortalecer sus redes de influencia en la provincia. Desde la prensa demócrata se censuró duramente el nombramiento de nuevos funcionarios como una de las prebendas que los diputados neo-católicos Nocedal, Vilches y Herreros manejaron, de forma arbitraria, para recompensar a sus respectivas clientelas los favores previamente recibidos durante los comi$\operatorname{cios}^{80}$. Conscientes del trascendental papel que jugaron las diputaciones en el entramado de poder liberal, prestaron una especial atención a las elecciones provinciales como mejor forma de cimentar desde abajo su basamento de apoyo $^{81}$. No resulta baladí que a la altura de noviembre, en plena campaña electoral, el corresponsal de El Pueblo en la antigua capital imperial afirmase que Toledo era desgraciadamente el país de los neos ${ }^{82}$. La paulatina deriva involucionista experimentada les llevó a desmarcarse de las posiciones parcialmente aperturistas de los gobiernos moderados de 1864 con el objetivo último de intentar rescatar a los progresistas del retraimiento. A menos moros menos ganancia, fue, según la correspondencia anterior, el lema que emplearon los neo-católicos toledanos para referirse al retraimiento de la oposición. La abstención de progresistas y demócratas alimentó el miedo a la revolución, temor que, al fin y al cabo, supieron explotar perfectamente en su propio beneficio para ganar adeptos a la causa de la religión. El nuevo golpe de timón experimentado en la cúpula del Ejecutivo supuso el trasvase del poder gubernamental a manos moderadas, una oportunidad propicia para recomponer sus filas. En Cuenca un colaborador de La Discusión auguró una dificultosa tarea a partir de la endeble situación en la que se encontró el partido en la capital y en el resto de la provincia, mermado por la sangría de correligionarios enrolados en las filas del unionismo o cooptados por la deriva reacciona-

Elecciones municipales, leg. 611, exp. 3; los de Guadalajara, en Archivo Municipal de Guadalajara (en adelante AMUGU), Elecciones, «Lista de los electores y elegibles para los cargos municipales. Año 1860», caja 688; y los de Toledo, en Archivo Municipal de Toledo (AMUTO), Elecciones 1857-1865, «Lista de electores y elegibles para cargos municipales. Año 1860», caja 1099.

${ }^{80}$ Sirvan como ejemplo los nombramientos efectuados en la administración de correos a favor del sobrino de Manuel María Herreros o del hermano del Alcalde de Consuegra, uno de los principales valedores del conde de Vilches en el distrito; El Pueblo, 27-IV-1864. La centralidad del favor como mecanismo esencial dentro de la dinámica clientelar ha sido puesta de manifiesto, entre una amplia nómina, por Javier MoReno LuZÓn, «Teoría del clientelismo y estudio de la política caciquil», Revista de Estudios Políticos, 89 (1995), pp. 191-224; y Xose Ramón VeIGa Alonso, «Anatomía del clientelismo político en la España liberal decimonónica: una realidad estructural», Hispania, 202 (1999), p. 647.

${ }^{81}$ La prensa demócrata censuró las presiones que los neocatólicos ejercieron desde Toledo para anular las actas de sus adversarios, como ocurrió en el caso de Miguel de la Barreda, electo por el distrito de Quintanar de la Orden, La Discusión, 9-I-1864.

82 El Pueblo, 16-XI-1864.

Hispania Sacra, LX

121, enero-junio 2008, 297-329, ISSN: 0018-215-X 
ria capitalizada por los neo-católicos, quienes gozaron de la anuencia y el respaldo del obispado conquense ${ }^{83}$.

Al igual que ocurrió en 1863, la lucha quedó circunscrita al campo del doctrinarismo. En la región los diputados neo-católicos se mantuvieron prácticamente incólumes, sólo mermados, al igual que el unionismo, a costa de la aplastante mayoría que obtuvieron los moderados a la sombra de la atalaya gubernamental ${ }^{84}$.

\section{DE LA RUPTURA CON EL LIBERALISMO AL ESTALLIDO REVOLUCIONARIO}

En el ámbito extraparlamentario, progresistas y demócratas urdían sus conspiraciones. La represión, una vez más, resultó, a los ojos de Narváez, el antídoto adecuado. Le había dado buenos resultados. Abarcó diversos frentes, desde una nueva y constrictiva ley de prensa a la involución ideológica que supuso la publicación en marzo de 1865 de la encíclica Quanta cura $^{85}$. En ella Pío IX condenó la libertad de cultos y el reconocimiento del Reino de Italia. Se había accedido a las presiones de los neo-católicos, quienes lanzaron públicamente sus diatribas contra el liberalismo y su incompatibilidad con el catolicismo. Un demócrata de la localidad minera de Hiendelaencina (Guadalajara) asimiló perfectamente el desdoblamiento de la ordenanza papal: su significación espiritual era indisociable de su contenido político de crítica denostada contra el régimen liberal ${ }^{86}$. La reacción también se afianzaba por el flanco derecho.

Bajo el prisma doctrinario, los unionistas se habían erigido desde la oposición en el perentorio recambio ministerial. A ello había contribuido su labor de desgaste gubernamental y sus interesados titubeos con la vía abstencionista, e, incluso, con la insurreccional. Isabel II no pudo renunciar a prescindir de la única alternativa de «orden» que todavía le quedaba, a pesar de las divergencias que le distanciaron de O'Donnell. Tal vez la más espinosa fue la cuestión italiana ${ }^{87}$. El Pensamiento Español publicó una exposición en la cual los neo-

${ }^{83}$ La Discusión, 22-IX-1864 y 1-X-1864.

${ }^{84}$ A excepción de José García Gutiérrez por Elche de la Sierra e Isidoro Ternero por Guadalajara, sustituidos por aspirantes moderados gubernamentales. Severo Catalina pasó del distrito de Alcázar de San Juan al de la capital conquense tras la renuncia de Juan Bautista Trúpita.

85 Sobre el particular véase Emilio LA PARRA LóPEZ,»La reina y la Iglesia», Juan Sisinio PÉREZ GARZÓn, (ed.): Isabel II..., op. cit., p. 212; y Begoña URIGÜEn, Orígenes y evolución..., op. cit., pp. 220-227.

${ }^{86}$ El Pueblo, 14-II-1865. Paradójicamente, Benigno Francia se mostró de acuerdo con el contenido espiritual o divino de la encíclica, no así con su significado humano o político.

87 Para profundizar al respecto, Fernando JiMÉNEZ NúÑEZ, Los gobiernos de Isabel II y la cuestión romana, Madrid, Ministerio de Asuntos Exteriores, 1988. 
católicos de Almagro mostraron su oposición a que el nuevo ministerio reconociese el Reino italiano ${ }^{88}$. Vino a reflejar el sentir de la fracción que desde el seno del moderantismo, en congruencia con la encíclica papal, había roto amarras con el liberalismo. La sacralización de la sociedad se erigió en su nuevo horizonte ${ }^{89}$. A su encuentro salieron los demócratas almagreños, quienes instaron al duque de Tetuán a tomar medidas en bien de la libertad, ya que hoy parece la invoca de nuevo, pues que ella y sólo ella puede destruir el ultramontanismo. La cita anterior sublima certeramente cuales fueron inicialmente los vectores de la política gubernamental. La mejor forma de combatir la reacción era atraerse a las fuerzas de la revolución. La cuestión italiana sólo fue una de las iniciativas dentro de un frente mucho más amplio que, destinado a satisfacer las reivindicaciones de la oposición, abarcó, entre otros asuntos, la reforma de la ley electoral, una menos constrictiva normativa de prensa y una reorganización administrativa.

Y es que la amenaza reaccionaria no era en absoluto un espejismo. Si la condena de la empresa legislativa del Bienio progresista desempeñó un papel ineluctable en la gestación del grupo, el reconocimiento del Reino de Italia puede considerarse el segundo gran elemento integrador del neo-catolicismo. La decisión del Gobierno de O'Donnell constituyó un verdadero hito, un salto cualitativo en el activismo desplegado por el partido católico. Sólo dos días antes de que Isabel II estampase su firma en el controvertido Decreto, el Gobernador de Toledo mostraba su preocupación e informaba al Ministro de la Gobernación ante el enérgico rechazo y resistencia que la decisión generó entre la cúpula -con voz en la prensa y las Cortes moderadas- y las «bases» neo-católicas de Toledo:

«Muy respetable Jefe: aquí hicieron eco las amenazas del Sr. Nocedal en el Congreso; y aunque muy reservadamente, se recogen firmas en la capital y fuera de ella para pedir a la Reina que no asienta el reconocimiento del Reino de Italia. Estaré en observación y obraré según convenga, a mi modo de ser, a menos que usted crea oportuno darme alguna instrucción» ${ }^{90}$.

A comienzos de julio Posada Herrera había ordenado a su delegado en Ciudad Real obstaculizar la recogida de firmas, iniciada en Almagro con si-

\footnotetext{
${ }^{88}$ Citada por La Democracia, 18-VII-1865.

89 Desde la prensa demócrata se censuró un bando del Alcalde neocatólico de Toledo en el que ordenó cerrar todos los establecimientos públicos de la ciudad (cafés, hosterías, etc,...) al toque de oraciones. Una disposición que bajo el prisma republicano no aspiró sino a ...convertir a la imperial ciudad en un cuartel o en un convento, aunque esto será más fácil por los muchos neos seglares y eclesiásticos que en su seno encierra; El Pueblo, 14-II-1865.

${ }^{90}$ AHPAS, Fondo Posada Herrera, caja 11.389, leg. 17 num. 7.
}

Hispania Sacra, LX

121, enero-junio 2008, 297-329, ISSN: 0018-215-X 
milar horizonte. Los suscriptores que, a propuesta de una sugerencia del Gobernador Civil plasmada en un telegrama cifrado, quedaron estigmatizados de cara a la arbitraria reestructuración de la administración en ciernes ${ }^{91}$. Una nueva reorganización partidista que no impidió que alcanzasen importantes cuotas de poder local, derivadas de la articulación de trabadas redes clientelares y de su infiltración en las instituciones vía elecciones locales, sólidos avales para afrontar con garantías las elecciones a Cortes de 1865 . Semanas antes de los comicios el Gobernador de Cuenca, en varias correspondencias, avisaba a Posada Herrera de la posición de fuerza con que ésta fracción los afrontaba y de los esfuerzos que habría que hacer en la lucha electoral y cuanto peligro se corre de no salir en ella airosos. Mientras la Unión Liberal todavía no había designado a sus aspirantes, los neo-católicos se agitan aquí de una manera ostensible y presentan ya sus candidatos, la propia casa del Secretario del Gobierno Civil ejercía como sede de las reuniones del Comité polaco neo-católico, los ayuntamientos de la provincia estaban dirigidos por los neo-católicos casi en su totalidad y en la Diputación los diputados neo-católicos combatieron tenazmente los nombramientos de funcionarios afines al unionismo ${ }^{92}$. Su homónimo toledano desgranó a su superior por las mismas fechas los elementos integrantes del grupo neo-católico de la provincia, formado por una base fuerte que le da un color reaccionario, la base es el clero. La misma circunscripción donde casi una década más tarde todavía existía repugnancia en votar a don Ambrosio González -candidato unionista resellado-, ya que no le perdonan haber votado la base segunda -durante el lejano Bienio progresista-93. Los primigenios referentes aglutinadores de la corriente mantenían su capacidad movilizadora casi diez años después.

Esta situación de fuerza de los correligionarios de Nocedal inclinó a Justo Hernández, uno de los prohombres unionistas de la provincia de Guadalajara, a prevenir a Posada Herrera sobre la necesidad de atraerse a los «resellados» arriacenses para contrarrestar la influencia omnímoda de que disfruta el bando absolutista -neo-católico-, entronizado en todos los puestos oficiales con muy raras excepciones ${ }^{94}$. Un activismo que explica su decisión de presentar candidaturas sin el decisivo beneplácito gubernamental, pero también los ulteriores

\footnotetext{
${ }^{91}$ Ibidem, caja 11.385, leg. 13 num. 7. Resulta aleccionadora la trascripción textual del telegrama, tanto la proposición del Jefe político: Sería prudente adoptar medidas contra empleados del Gobierno o municipales que firmen exposición sobre Italia; como la eufemística respuesta del Ministro asturiano: Tenga usted presente para dentro de unos días a los firmantes.

92 Ibidem, caja 11.386, leg. 14 num. 3.

93 Ibidem, caja 11.389, leg. 17 num. 7.

94 Ibidem, caja 11.400, leg. 28 num. 12.
} 
resultados cosechados. Toledo, con Nocedal y Herreros; y Cuenca, con Catalina y Coronado fueron las provincias donde alcanzaron representación ${ }^{95}$. No resultó casual. Eran sus tradicionales bastiones, La primera, sede arzobispal, la segunda, capital de la diócesis ${ }^{96}$. Si bien no gozaron del apoyo que anteriores gabinetes moderados les brindaron tampoco el nuevo Ejecutivo unionista planteó una férrea resistencia electoral. Era necesario ofrecer una imagen pseudo-legalista de los comicios que neutralizase en la medida de lo posible las ya palpables derivas revolucionarias.

Por eso desde el poder central fueron desechados los esfuerzos solicitados por el Jefe político conquense en 1865 para superar los grandes obstáculos que existían en una provincia dominada casi exclusivamente por el clero ${ }^{97}$. Las pocas medidas, el eufemismo para referirse a las irregularidades, demandadas con el objetivo de contrarrestar la influencia ejercida por los eclesiásticos, fueron desautorizadas y certificaron la derrota cosechada por los candidatos gubernamentales $^{98}$. Las razones de la capitulación ministerial fueron expuestas dos semanas más tarde por el Jefe político de la provincia:

«El clero, impulsado por este Diocesano, ha echado el resto en la lucha, presentándose muchos de los curas párrocos al frente de sus feligreses excitándolos a votar contra los enemigos de la religión y del Papa. Si cuando se discuta en las Cortes el discurso de la

95 De amalgama repugnante y escandalosa fue tildado el conjunto de candidatos unionistas y neocatólicos que obtuvieron acta en el comunicado de agradecimiento que el Comité Progresista de Toledo envió a sus correligionarios felicitándoles por haber rehusado votar; La Soberanía Nacional, 12-XII1865. Una supuesta amalgama que, fundada a partir de las críticas globales de los abstencionistas, no llegó a existir. Lo prueba la candidatura unionista oficial autorizada por el puño y letra de Posada Herrera, en la cual no aparecía el nombre de los aspirantes neocatólicos: duque de Frías, Bernardino Núñez Arenas, Ambrosio González, conde de Vilches y Eulogio Benayas; AHPAS, Fondo Posada Herrera, caja 11.389, leg. 17 num. 7. En Cuenca el Comité del Partido moderado de la provincia aprobó una candidatura en la cual estuvieron integrados los neo-católicos Catalina y Coronado, junto a los moderados José Juan Navarro, Luis Sartorius y el conde de Retamoso; AHPAS, Fondo Posada Herrera, caja 11.386, leg. 14 num. 3. Una lista que no viene explicitada en las candidaturas neo-católicas independientes publicadas por El Pensamiento Español entre el 21 y el 25 de noviembre que indujeron a pensar a Begoña URIGÜEN que las tradicionales alianzas electorales con los moderados habían desaparecido; Orígenes y evolución..., op. cit., pp. 249-250.

96 Una influencia similar ejerció el obispado del Burgo de Osma en el soporte electoral que recibió el moderantismo y el neo-catolicismo en dicho distrito soriano; Margarita CABALLERo, El Sufragio Censitario..., op . cit., p. 209; o en Solsona y Urgel en la provincia de Lérida, Josep María Pons I ALTÉS, Moderats i progressistes..., op. cit., p. 118.

97 Ibid., caja 11.386, leg. 14, num. 3.

98 Sólo el unionista Modesto Gosálvez Barceló eclipsó la victoria obtenida por los candidatos moderados (Luis José Sartorius y el conde de Retamoso) y neocatólicos (Carlos María Coronado y Severo Catalina), todos ellos integrantes de una candidatura apoyada por el clero y la Junta Provincial del Partido moderado tras la reunión celebrada en la capital conquense el 16 de noviembre de 1865; AHPAS, Fondo Posada Herrera, caja 11.386, leg. 14, num. 3. ACD, Series de Documentación Electoral, leg. 54, num. 2 .

Hispania Sacra, LX

121, enero-junio 2008, 297-329, ISSN: 0018-215-X 
Corona necesita usted tomar acta de estos hechos que tanto daño causan a nuestra religión y que desprestigian el sacerdocio arrastrándolo por el fango de la política, remitiré a usted una nota circunstanciada de los curas que más se han distinguido en la campaña y de los Alcaldes que han observado la misma conducta» ${ }^{99}$.

El apoyo del clero a los candidatos moderados, al que su prelado excita con todos los medios que tiene a su alcance, la publicación en el Boletín Eclesiástico del Obispado de Cuenca de una circular en la que el Obispo estimuló a sus subordinados a no apoyar en ningún terreno -en inequívoca referencia a las elecciones- a ninguna persona que trabaje en sentido opuesto al episcopado católico -una alusión directa al Gobierno y sus aspirantes- y las instrucciones que proporcionó a 120 eclesiásticos reunidos en la capital con motivo de la provisión de plazas de curas párrocos para que combatan enérgicamente a los candidatos de Unión Liberal, fueron, sin duda, decisivas ${ }^{100}$. Si bien sería un error atribuir la derrota exclusivamente a la influencia ejercida por los curatos, según la despectiva denominación empleada por el Gobernador Civil, resulta innegable el carácter determinante de su alineamiento en la elección de los dos candidatos neo-católicos, y, en menor medida, en la victoria de los enfeudados, Luis José Sartorius y del conde de Retamoso ${ }^{101}$. Los porcentajes que arroja el censo de la sección capitalina resultan sugerentes:

99 AHPAS, Fondo Posada Herrera, caja 11.386, leg. 14, num. 3.

100 Uno de los fragmentos de la circular eclesiástica que el Gobernador Civil subrayó y envió a Posada como prueba de la hostilidad desplegada por el Obispo conquense hacia el Gobierno decía así: $S a$ bido es lo que recientemente ha proclamado el Episcopado español acerca de las cosas de Italia, acerca de la libertad de enseñanza en los establecimientos literarios y desenfreno de la prensa. La doctrina de los obispos ha de ser la norma de conducta de toda su grey, pero especialmente de todos los eclesiásticos de todas categorías. Estos, pues, ni pueden enseñar otra doctrina que la de sus pastores ni honrar con su confianza en los cargos indicados y otros cualesquiera, a los que profesan la contraria, ni apoyar directa ni indirecta, próxima ni remota, explicita ni implícitamente, en ningún caso ni en ningún terreno, a cualquier persona de quien les consta que ha de trabajar en sentido opuesto a las sanas, autorizadas y seguras enseñanzas del episcopado católico; Boletín eclesiástico del Obispado de Cuenca, num. 44, 6-XI-1865, p. 107; en Idem.

101 En la carta que el Gobernador envió a Posada con un informe detallado del transcurso de las elecciones, tras disculparse por la derrota sufrida por el Gobierno, siento sinceramente el desengaño que acaba de llevar, y puedo asegurar a usted que a no ser por los esfuerzos que yo hice en su obsequio, como demostraré si fuese necesario demostrarlo...; achacó la derrota a las trabadas redes caciquiles de los dos prohombres moderados de la provincia, ...en las secciones de Tarancón y de Priego, donde los Condes de Retamoso y San Luis han tenido siempre una inmensa mayoría, y en las cuales cuentan hoy con todos los Ayuntamientos incluidos sus secretarios, con los jueces de paz y con algunos funcionarios públicos que son en su totalidad hechuras de aquellos señores y que se han presentado en su mayoría en abierta y ostensible hostilidad contra los candidatos de la Unión Liberal; y, como no, al clero, que ha echado el resto en la lucha, y resultó especialmente decisivo en la elección de Catalina y Coronado; Idem. 
CuAdro II: Censo electoral de la sección de Cuenca según la nueva ley de 1865. Año 1865

\begin{tabular}{|l|l|c|c|c|}
\hline \multicolumn{2}{|c|}{ Electores } & Capital & Distrito & Total \\
\hline $\begin{array}{l}\mid l \\
\text { Contribuyentes directos con cuota superior } \\
\text { a 20 escudos }\end{array}$ & $305(36.48 \%)$ & $531(63.52 \%)$ & $836(71.08 \%)$ \\
\hline \multirow{5}{*}{ Capacidades } & $\begin{array}{l}\text { Empleados Adm. y } \\
\text { profesiones liberales }\end{array}$ & $158(70.85 \%)$ & $65(29.15 \%)$ & $223(18.96 \%)$ \\
\cline { 2 - 5 } & $\begin{array}{l}\text { Eclesiásticos (cabildo y } \\
\text { párrocos) }\end{array}$ & $51(50 \%)$ & $51(50 \%)$ & $102(8.67 \%)$ \\
\cline { 2 - 5 } & Oficiales militares retirados & $14(93.33 \%)$ & $1(6.66 \%)$ & $15(1.27 \%)$ \\
\cline { 2 - 5 } & Total electores capacidades & $223(65.58 \%)$ & $117(34.41 \%)$ & $340(28.91 \%)$ \\
\cline { 2 - 5 } & Total & $528(44.8 \%)$ & $648(55.1 \%)$ & 1176 \\
\hline
\end{tabular}

Fuente: AMUCU, Elecciones de Diputados a Cortes, leg. 617, exp. 5.

Tras los empleados de la administración y los profesionales liberales, los eclesiásticos constituyeron el colectivo más beneficiado por la reforma electoral. La eliminación de las trabas pecuniarias a los miembros de los cabildos, a los párrocos y a sus tenientes y coadjutores, motivó la nada desdeñable irrupción masiva del clero secular en el censo. Supusieron un $8.97 \%$ del electorado y se distribuyeron de forma ecuánime entre el distrito y la capital, donde la concentración del Cabildo catedralicio en Cuenca fue atemperada por la presencia de, al menos, un párroco en cada uno de los pueblos del distrito. En su intento por hacer desistir a la oposición de su política de retraimiento el Gobierno unionista aminoró la presión sobre el corsé establecido por la anterior ley electoral sobre las capacidades, sector en el que progresistas y demócratas reclutaron a un porcentaje importante de correligionarios. Esta medida tuvo un efecto no deseado para la política o'donnellista: la inclusión del enervado clero secular y su repercusión en los resultados electorales ${ }^{102}$. Las consecuencias fueron todavía más acusadas en la sección capitalina toledana:

${ }^{102}$ La reforma electoral triplicó el censo del distrito de Cuenca, de 377 en 1864 pasó a 1176 electores en 1865; ACD, Series de Documentación Electoral, leg. 57 num. 3.

Hispania Sacra, LX

121, enero-junio 2008, 297-329, ISSN: 0018-215-X 
CuADRO III: Distribución profesional de los electores a Cortes en la sección de Toledo según la ley electoral de 1865. Año 1865

\begin{tabular}{|c|c|c|c|c|}
\hline \multicolumn{2}{|r|}{ Electores } & Capital & Distrito & Total \\
\hline \multirow{6}{*}{ Contribuyentes } & Artesanos y trabajadores & $32(91.42 \%)$ & $3(8.57 \%)$ & $35(3.37 \%)$ \\
\hline & Comerciantes y fabricantes & $120(83.33 \%)$ & $24(16.67 \%)$ & $144(15.5 \%)$ \\
\hline & Eclesiásticos & $17(94.44 \%)$ & $1(5.56 \%)$ & $18(1.93 \%)$ \\
\hline & Profesiones liberales & $53(96.36 \%)$ & $2(3.64 \%)$ & $55(5.92 \%)$ \\
\hline & Propietarios y arrendatarios & $119(28.67 \%)$ & $296(71.33 \%)$ & $415(44.7 \%)$ \\
\hline & Total contribuyentes & $342(51.19 \%)$ & $326(48.81 \%)$ & $668(71.9 \%)$ \\
\hline \multirow{4}{*}{ Capacidades } & Eclesiásticos & $84(83.16 \%)$ & $17(16.84 \%)$ & $101(10.8 \%)$ \\
\hline & $\begin{array}{l}\text { Empleados Adm. y prof. } \\
\text { Liberales }\end{array}$ & $100(77.51 \%)$ & $29(22.49 \%)$ & $129(13.9 \%)$ \\
\hline & Militares & $30(100 \%)$ & 0 & $30(3.23 \%)$ \\
\hline & Total capacidades & $214(82.3 \%)$ & $46(17.7 \%)$ & $260(28.1 \%)$ \\
\hline \multicolumn{2}{|l|}{ Total electores } & $556(59.91 \%)$ & $372(40.09 \%)$ & 928 \\
\hline
\end{tabular}

Fuente: AMUTO, Elecciones 1857-1865, caja 1099. Elaboración propia.

Junto al apoyo numérico, ideológico y organizativo del clero, la infiltración clientelar en las instituciones o las campañas de prensa, los candidatos neo-católicos tampoco renunciaron a obtener rédito electoral gracias a la efectiva compulsión ejercida a partir de la posesión de recursos productivos. ¡Qué mejor testimonio que el de un coetáneo! Resulta lapidario el fragmento de la carta en la que el Gobernador de Cuenca informaba a Posada de las armas con que contaban los candidatos neo-católicos en la provincia a la altura de 1865:

«Severo Catalina, de opiniones neo-católicas, como usted sabe muy bien...es hoy el principal agente de los reaccionarios y el que ha decidido a este obispo a entrar en la lucha electoral...es más que probable que en el resto de la provincia no obtenga más sufragios que los que pueda proporcionarle el clero y los que apoyan por consideraciones de partido toda la candidatura moderada...D. Carlos María Coronado...cuenta en él -en Huete- con algunas simpatías entre los absolutistas puros pero en el resto de la provincia tiene muy pocos amigos. Sin embargo de esto su hermano Leoncio es Administrador de las casas de Montijo y de Moya, que tienen en esta provincia y particularmente en la sección de Cañete gran número de colonos, podrá obtener con el apoyo de éstos algunos votos a su favor...»103.

103 AHPAS, Fondo Posada Herrera, caja 11.386, leg. 14 num. 3. He profundizado sobre esta cuestión en otro trabajo; «Cuestiones sobre caciquismo isabelino: revisión de unas inercias historiográficas», I Encuentro de Jóvenes Historiadores en Historia Contemporánea de la A. H. C., Zaragoza, 2007 (en prensa). 
El progresista toledano Luis Carrillo, constituyente en 1854, confeccionó, bajo el prisma abstencionista, un detallado análisis de las elecciones de 1865, a partir de los perfiles concretos que revistieron las votaciones en su distrito natal, Sonseca ${ }^{104}$. El retraimiento de los buenos liberales -demócratas y progresistas- había dado sus frutos en el partido judicial: apenas un $20 \%$ del electorado tomó parte en la elección ${ }^{105}$. En el extremo opuesto, las directrices legalistas y las trabadas redes de influencia que los neo-católicos habían conseguido articular en la provincia terminaron por convencer a las autoridades unionistas de la dificultad de plantarles batalla ${ }^{106}$. Esta circunstancia coadyuvó a que los dos candidatos neos, Nocedal y Herreros, gozasen de la desidia gubernamental, aún siendo consciente el Ejecutivo o'donnellista de la oposición reaccionaria a la que habrían de enfrentarse en las futuras Cortes. Baste recordar los discursos que Manuel María Herreros pronunció en la Cámara baja a favor de un proyecto que aspiró a emular la represiva normativa de prensa elaborada en 1857 por su mentor, Cándido Nocedal ${ }^{107}$.

En los lugares donde los neo-católicos no contaron con una sólida plataforma de apoyo, sus candidatos quedaron eclipsados por los aspirantes ministeriales o, aunque de forma minoritaria al considerarse el voto como una obligación moral, sus votantes optaron por la abstención ${ }^{108}$. Así ocurrió en Caudete (Albacete), donde un demócrata de la localidad informó sobre la decisión adoptada por los neos locales, quienes justificaron su retraimiento como una forma de protesta hacia las medidas desplegadas por los unionistas contra la religión, en inequívoca referencia a la espinosa cuestión italiana ${ }^{109}$. Este vidrioso asunto empujó, a Aparisi y Guijarro a abandonar, en señal de protesta y definitivamente, la actividad parlamentaria ${ }^{110}$. Participar o abstenerse: el neo-catolicismo era jalonado por los mismos debates que atravesaron al resto de culturas políticas liberales ${ }^{111}$. No obstan-

104 El Pueblo, 16-XII-1865.

105 Sólo 180 de los 777 concurrieron a las urnas.

106 Según el testimonio de Luis Carrillo, sólo en el partido de Sonseca controlaron los municipios de Yébenes (en el cual era alcalde el hermano de Manuel María Herreros), Ajofrín, Manjaliza y Mazarambroz.

${ }_{107}$ DSC, num. 66, 13-IV-1866, pp. 981 y 989-990. Proyecto que finalmente fue desechado por la mayoría unionista.

108 Desde los primeros inicios de la andadura liberal sus principales líderes y órganos de expresión incidieron en la necesidad de movilizar al electorado católico, situando el ejercicio del voto en el terreno de las obligaciones morales. El objetivo, apoyar la opción política que con mayor encono defendiese la causa de la religión. Un proceso atestiguado desde las elecciones de septiembre 1843, María Cruz ROMEO MATEO, «Política católica para después de la revolución o las vías del antiliberalismo: Aparici y Guijarro, 1843-1844», Trienio, 41 (2003), p. 150.

109 El Pueblo, 20-XII-1865.

110 Francisco Villacorta Baños, La derrota intelectual..., op. cit., p. 46.

111 Un resumen del debate abstencionista y de las posturas adoptadas por demócratas y progresistas en torno a esta estrategia, en Florencia Peyrou, La Comunidad de Ciudadanos. El Discurso Democrático-Republicano en España, 1840-1868, Pisa, Edizioni Plus-Pisa University Press, 2006, pp. 62-70.

Hispania Sacra, LX

121, enero-junio 2008, 297-329, ISSN: 0018-215-X 
te, el donosiano terror al socialismo y la república social pesaron mucho más en la balanza' ${ }^{112}$.

Agotados los intentos por rescatar a los progresistas del ostracismo, la defenestración de los unionistas fue cuestión de tiempo. Ante la inminencia de la revolución, los moderados se erigieron en el recurso autoritario más propicio para combatirla, a pesar de los méritos atesorados por el unionismo en la represión de los levantamientos sediciosos liderados por Prim. A comienzos de julio, Isabel II depositó por última vez su confianza en Narváez iniciando una larga agonía, caracterizada por la deriva autoritaria y reaccionaria impuesta por el sector más radical del moderantismo ${ }^{113}$. Libertades individuales y garantías constitucionales fueron constreñidas en aras a evitar la sacudida revolucionaria.

El señuelo de O'Donnell no había dado los resultados esperados. Sus medidas estuvieron al límite de romper los puentes existentes entre neos y moderados, heridas suturadas con la subida al poder de Narváez. Las veleidades ultraconservadoras experimentadas por el moderantismo acercaron posturas y afinidades entre ambos. Ante esta dialéctica, pocas sorpresas arrojaron las elecciones a Cortes celebradas en marzo de 1867. El retraimiento unionista, medida de presión que reveló sus esperanzas de que la soberana les concediese una nueva oportunidad, coadyuvó a la configuración de unas Cortes monocolores. Con unas bases cercenadas, el moderantismo recompuso sus filas con la entrada en el Congreso de caras nuevas. Francisco Garvía y Valentín Maroto, con sus actas por la provincia Toledo, engrosaron las filas de la incólume fracción neocatólica ${ }^{114}$. Dentro de los espacios permeables que sellaron su transitoria reconciliación entre la fracción nucleada en torno a Nocedal y el Ejecutivo NarváezGonzález Bravo no entró la definitiva ruptura con los mecanismos representativos. Era una frontera que Narváez, pese a la tenue pseudo-legalidad existente, no estaba dispuesto a cruzar. El horizonte contrarrevolucionario anhelado por Nocedal necesitaba una nueva cúspide que no fuese Isabel II ${ }^{115}$. Una ruptura sellada en los meses del verano de 1868. La revolución acechaba y el neo-catolicismo se apresuró a desmarcarse de la soberana. Tras la «Gloriosa», e integrado en el magma de corrientes que engrosaron la familia tradicionalista, continuaría con la defensa de la causa de la religión bajo nuevas fórmulas.

112 Antonio RIVERA GARCíA, Reacción y revolución..., op. cit., pp. 198-203; expresiones extraídas de la obra de Donoso Cortés titulada Ensayo sobre el catolicismo, el liberalismo y el socialismo, Madrid, 1851 .

113 Para profundizar en este proceso, véase Gonzalo Capellán de Miguel y Fidel Gómez OchoA, El marqués de Orovio..., op. cit., pp. 64-65.

114 Por Cuenca y Toledo revalidaron elección Carlos María Coronado, Severo Catalina, Manuel María Herreros y Cándido Nocedal.

115 A pesar de que Nocedal fue el último refugio de legitimación simbólica que le quedó a la monarquía isabelina, Isabel BURDIELL,»La consolidación del liberalismo y el punto de fuga de la monarquía», en Manuel SuÁrez Cortina, (ed.), Las máscaras de la libertad..., op . cit., p. 107. 